\title{
Tom Hanafan River's Edge Park, Phase 1 Methods
}

\section{Research Fellow:}

Catherine De Almeida

Assistant Professor of Landscape Architecture

University of Nebraska-Lincoln

Research Assistants:

Brandon Zambrano and Hannah LoPresto

BLA Candidates

University of Nebraska-Lincoln

\section{Firm Liaison:}

Susannah Ross

Senior Associate

Sasaki Associates

This investigation was conducted as part of the Landscape Architecture Foundation's 2018 Case Study Investigation (CSI) program. CSI matches faculty-student research teams with design practitioners to document the benefits of exemplary high-performing landscape projects. Teams develop methods to quantify environmental, economic and social benefits and produce Case Study Briefs for LAF's Landscape Performance Series.

To cite:

De Almeida, Catherine, Hannah LoPresto, and Brandon Zambrano. "Tom Hanafan River's Edge Park Methods." Landscape Performance Series. Landscape Architecture Foundation, 2018. https://doi.org/10.31353/cs1351

The full case study can be found at:

https://landscapeperformance.org/case-study-briefs/tom-hanafan 


\section{Overview}

Located along the Missouri River in Council Bluffs, lowa, Tom Hanafan River's Edge Park reclaims the Missouri River floodplain for native ecological riparian communities and human access to the river. The site is known for experiencing the Great 2011 Flood; one of the worst floods in the area's recent history, resulting in immense property damages. Because of this flood event, the site of Tom Hanafan River's Edge Park not only presented an opportunity to preserve and restore the riparian forest in the floodplain, but also to withstand a 500-year storm event. This reclamation is achieved through the revitalization of the riparian forest with native tree plantings along the northern and southern areas surrounding the park's open space, and a native meadow mix planted along the Army Corps of Engineers' levee turned amphitheater. Previously deteriorated by ATV use and invasive species, Tom Hanafan River's Edge Park converted a landscape of misuse to a friendly, highly accessible public park.

The following Methods document presents a variety of data collection and analysis methodologies, both on and off site. Tree sampling was done on site to obtain DBH averages to calculate carbon sequestration for a total of 621 planted trees. User surveys were distributed during evening events and on typical days to quantify user perception of the park. Various online tools such as the EPA National Stormwater Calculator and Council Bluff's County Assessor allowed the research team to illustrate not only environmental resilience to flood damage, but also the economic and social resiliency of the park.

Site development from 2005 - 2017, including imagery of the 2011 Flood

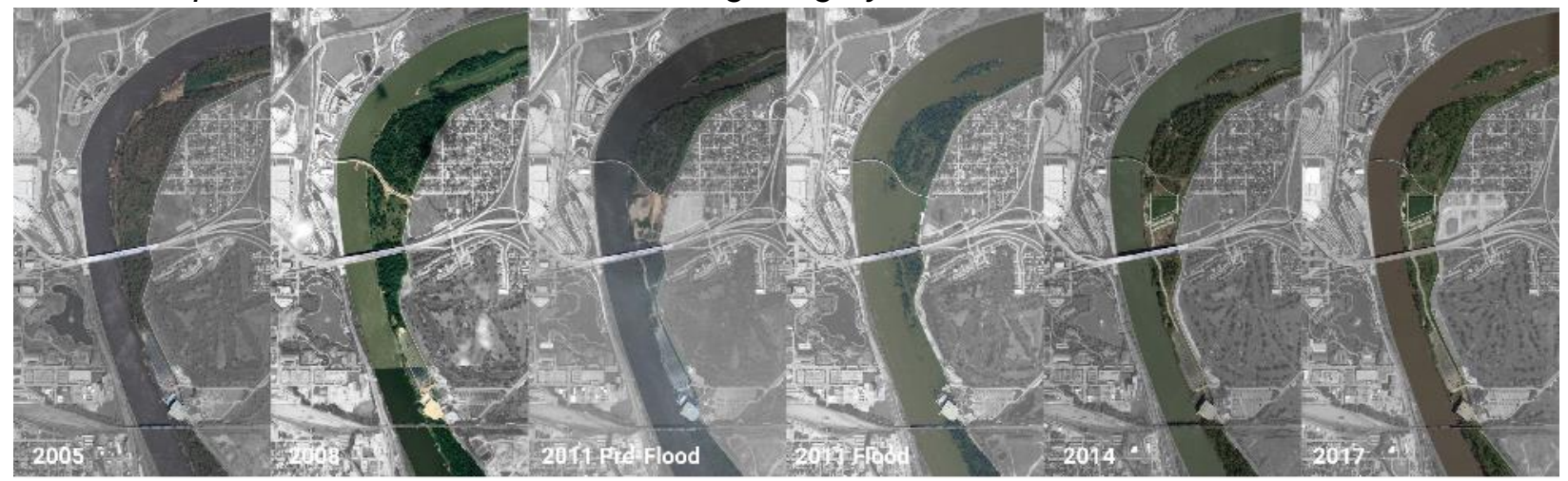

Aerial imagery from Google Earth Pro

Author: Brandon Zambrano

\section{Table of Contents}

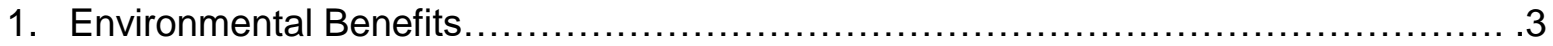

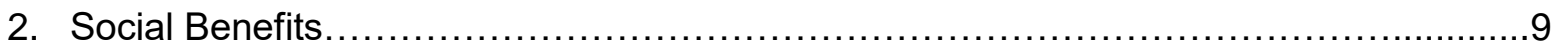

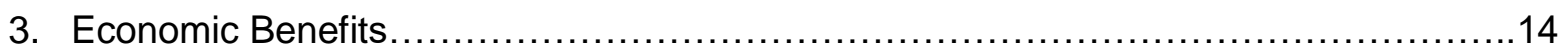

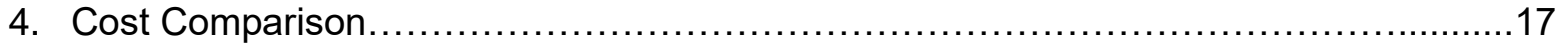

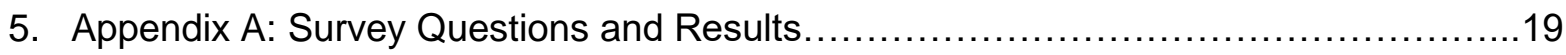

6. Appendix B: EPA National Stormwater Calculator Report...........................36

7. Appendix C: City of Council Bluffs Fiscal Year 2017 Budget to Actual Revenue............44 


\section{Environmental Benefits}

- Sequesters 86,685 lbs of atmospheric carbon annually in 621 newly-planted trees.

\section{Methods:}

Prior to the park, this area was a low-quality woodland with significant populations of invasive species-resulting in many trees needing to be removed and replaced. Part of the firm's design strategy was to rehabilitate the riparian woodland on the northern and southern portion of the property. Additionally, two tree groves were planted on the north and south sides of the Great Lawn.

Due to the large quantity of trees planted, up to 5 of each tree species on site had their circumference at breast height (4.5 ft. up from the tree base) and location inventoried. Circumference was then translated to average diameter of each species (Table 1.1). Because some species were planted in a variety of environmental conditions on site (such as in turf versus bioswale), specimens from both conditions were factored into the species average to obtain a more comprehensive DBH average for the site (see Table 1.1). Some specific species, such as swamp white oak and American yellowwood, had fewer than 5 measurements taken for their average because of lower planted numbers and difficulties with physical accessibility to certain species on site. To calculate the amount of carbon reduction provided by these trees per year, i-Tree Streets software was utilized. When a species was not available to enter, the genus was used instead. The tree species, average $\mathrm{DBH}$, and land use was entered into this calculator (see Table 1.2). The amount of atmospheric carbon reduction per year was then multiplied by the number of trees on site of that specific species. All totals were added to obtain a total annual reduction of atmospheric carbon on-site.

\section{Calculations:}

Table 1.1: Tree Specimen Circumference and Average Diameter (DBH)

\begin{tabular}{|c|c|c|c|c|c|c|c|c|c|c|c|c|}
\hline & $\begin{array}{l}\# 1 \\
\text { Circ. }\end{array}$ & $\begin{array}{l}\# 2 \\
\text { Circ. }\end{array}$ & $\begin{array}{l}\# 3 \\
\text { Circ. }\end{array}$ & $\begin{array}{l}\# 4 \\
\text { Circ. }\end{array}$ & $\begin{array}{l}\# 5 \\
\text { Circ. }\end{array}$ & $\begin{array}{l}\text { \#6 } \\
\text { Circ. }\end{array}$ & $\begin{array}{l}\# 7 \\
\text { Circ. }\end{array}$ & $\begin{array}{l}\text { \#8 } \\
\text { Circ. }\end{array}$ & $\begin{array}{l}\# 9 \\
\text { Circ. }\end{array}$ & $\begin{array}{l}\text { Avg. } \\
\text { Circ. }\end{array}$ & $C=\pi d$ & $\begin{array}{l}\text { Avg. } \\
\text { DBH }\end{array}$ \\
\hline $\begin{array}{l}\text { Red Sunset Red } \\
\text { Maple } \\
\text { Acer rubrum } \\
\text { 'Red Sunset' }\end{array}$ & $1^{\prime}-4 "$ & & & & & & & & & $16 "$ & $16=\pi d$ & $5.09 "$ \\
\hline $\begin{array}{l}\text { Sun Valley Red } \\
\text { Maple } \\
\text { Acer rubrum } \\
\text { 'Sun Valley' }\end{array}$ & $1^{\prime}-5 "$ & $1^{\prime}-4 "$ & $1^{\prime}-5 "$ & $1^{\prime}-4 "$ & $1^{\prime}-9 "$ & & & & & $17.4^{\prime \prime}$ & $17.4=\pi d$ & $5.54 "$ \\
\hline $\begin{array}{l}\text { Autumn Blaze } \\
\text { Freeman Maple } \\
\text { Acer } x \text { freemanii } \\
\text { 'Autumn Blaze' }\end{array}$ & $1^{\prime}-4.5^{\prime \prime}$ & $1^{\prime}-9.5^{\prime \prime}$ & & & & & & & & $19 "$ & $19=\pi d$ & $6.05^{\prime \prime}$ \\
\hline $\begin{array}{l}\text { Allegheny } \\
\text { Serviceberry } \\
\text { Amelanchier } \\
\text { laevis } \\
\text { 'Snowcloud' } \\
\text { Bioswale } \\
\text { Turf }\end{array}$ & $6 "$ & $6.5^{\prime \prime}$ & $6.5^{\prime \prime}$ & $6.5^{\prime \prime}$ & $6.5^{\prime \prime}$ & $5.5^{\prime \prime}$ & $5.5^{\prime \prime}$ & & & $6.14^{\prime \prime}$ & $6.14=\pi d$ & $1.95^{\prime \prime}$ \\
\hline
\end{tabular}




\begin{tabular}{|c|c|c|c|c|c|c|c|c|c|c|c|c|}
\hline $\begin{array}{l}\text { Heritage River } \\
\text { Birch } \\
\text { Betula nigra } \\
\text { 'Heritage' } \\
\text { Parking Lot } \\
\text { Beach }\end{array}$ & $1^{\prime}-4 "$ & 1'-2" & $8.5^{\prime \prime}$ & 1'-3.5" & $1 '$ & 1'-7" & 1'-3" & $11 "$ & 1'-7" & $14.44 "$ & $14.44=\pi d$ & $4.6 ”$ \\
\hline $\begin{array}{l}\text { American } \\
\text { Yellowwood } \\
\text { Cladrastis } \\
\text { Kentukea }\end{array}$ & 1'-3" & 1'-2" & $11 "$ & & & & & & & $13.33^{\prime \prime}$ & $13.33=\pi d$ & $4.24 "$ \\
\hline $\begin{array}{l}\text { Sycamore } \\
\text { Platanus } \\
\text { occidentalis }\end{array}$ & $1^{\prime}-5.5^{\prime \prime}$ & $1^{\prime}-5^{\prime \prime}$ & 1'-3.5" & 1'-4" & $1^{\prime}-4 "$ & & & & & $16.4 "$ & $16.4=\pi d$ & $5.22 "$ \\
\hline $\begin{array}{l}\text { Swamp White } \\
\text { Oak } \\
\text { Quercus bicolor }\end{array}$ & 1'-2" & 1'-1.5" & & & & & & & & 13.75 & $13.75=\pi d$ & $4.38 "$ \\
\hline $\begin{array}{l}\text { Bur Oak } \\
\text { Quercus } \\
\text { macrocarpa }\end{array}$ & $1^{\prime}$ & $1^{\prime}-2.5^{\prime \prime}$ & $1^{\prime}$ & $10.5 "$ & $11 "$ & & & & & $12 "$ & $12=\pi d$ & $3.82 "$ \\
\hline
\end{tabular}

Table 1.2: Total Street Tree Atmospheric Carbon Reduction

\begin{tabular}{|c|c|c|c|c|c|c|}
\hline Species & Average DBH (inches) & Land Use & $\begin{array}{l}\text { Atmospheric } \\
\text { Carbon } \\
\text { Reduction Per } \\
\text { Year (Ibs) }\end{array}$ & \# of Trees & Calculation & $\begin{array}{l}\text { Total Atmospheric } \\
\text { Carbon Reduction } \\
\text { by Species Per } \\
\text { Year (Ibs) }\end{array}$ \\
\hline $\begin{array}{l}\text { Red Sunset Red Maple } \\
\text { Acer rubrum 'Red Sunset' }\end{array}$ & $5.09 "$ & Park, or other vacant land & 132 & 26 & $132 \times 26$ & 3,432 \\
\hline $\begin{array}{l}\text { Sun Valley Red Maple } \\
\text { Acer rubrum 'Sun Valley' }\end{array}$ & $5.54 "$ & Park, or other vacant land & 157 & 36 & $157 \times 36$ & 5,652 \\
\hline $\begin{array}{l}\text { Autumn Blaze Freeman } \\
\text { Maple } \\
\text { Acer } x \text { freemanii 'Autumn } \\
\text { Blaze' }\end{array}$ & $6.05^{\prime \prime}$ & Park, or other vacant land & 185 & 52 & $185 \times 52$ & 9,620 \\
\hline $\begin{array}{l}\text { Allegheny Serviceberry } \\
\text { Amelanchier laevis } \\
\text { 'Snowcloud' }\end{array}$ & $1.95 "$ & Park, or other vacant land & 23 & 48 & $23 \times 48$ & 1,104 \\
\hline $\begin{array}{l}\text { Common Serviceberry } \\
\text { Amelanchier arborea }\end{array}$ & $2.23 "$ & Park, or other vacant land & 29 & 43 & $29 \times 43$ & 1,247 \\
\hline $\begin{array}{l}\text { Heritage River Birch } \\
\text { Betula nigra 'Heritage' }\end{array}$ & $4.6 "$ & Park, or other vacant land & 165 & 91 & $165 \times 91$ & 15,015 \\
\hline $\begin{array}{l}\text { American Yellowwood } \\
\text { Cladrastis Kentukea }\end{array}$ & $4.24 "$ & Park, or other vacant land & 147 & 21 & $147 \times 21$ & 3,087 \\
\hline $\begin{array}{l}\text { Common Honeylocust } \\
\text { Gleditsia triacanthos var. } \\
\text { Inermis 'Skyline' }\end{array}$ & $5.91 "$ & Park, or other vacant land & 221 & 145 & $221 \times 145$ & 32,045 \\
\hline $\begin{array}{l}\text { Sycamore } \\
\text { Platanus occidentalis }\end{array}$ & $5.22 "$ & Park, or other vacant land & 162 & 27 & $162 \times 27$ & 4,374 \\
\hline
\end{tabular}




\begin{tabular}{|l|l|l|l|l|l|l|}
\hline $\begin{array}{l}\text { Swamp White Oak } \\
\text { Quercus bicolor }\end{array}$ & $4.38^{\prime \prime}$ & Park, or other vacant land & 154 & 2 & $154 \times 2$ & 308 \\
\hline $\begin{array}{l}\text { Bur Oak } \\
\text { Quercus macrocarpa }\end{array}$ & $3.82^{\prime \prime}$ & Park, or other vacant land & 96 & 57 & $96 \times 57$ & 5,472 \\
\hline $\begin{array}{l}\text { Bald Cypress } \\
\text { Taxodium distichum }\end{array}$ & $5.35^{\prime \prime}$ & Park, or other vacant land & 73 & 73 & $73 \times 73$ & 5,329 \\
\hline & & & & $\begin{array}{l}\text { Total \# of } \\
\text { Trees: } \\
621\end{array}$ & & $\begin{array}{l}\text { Total Atmospheric } \\
\text { Carbon Reduction } \\
\text { On Site Per Year } \\
\text { (Ibs): 86,685 }\end{array}$ \\
\hline
\end{tabular}

\section{Sources:}

Tree Plan provided by Sasaki

i-Tree Streets software by i-Tree

\section{https://www.itreetools.org/streets/}

\section{Limitations:}

1. With environmental conditions differing across the site (turf, bioswales, beach, etc.) trees of the same species may have varying DBH values.

2. While on site, slight differentiation in some species was observed compared to the construction documents.

3. The calculations above assume that the proposed number of trees was planted. This excludes the Japanese stewartia (never planted) and London plane trees (replaced with honey locusts).

4. Upon on-site observation, some American yellowwoods were replaced with other species or in poor condition, resulting in a slight discrepancy between number of proposed trees versus actual planted trees.

5. In a few cases, the number of measurements per species was limited due to physical accessibility to certain species.

6. Only newly planted trees were inventoried. However, older trees remain on site which are also contributing to atmospheric carbon sequestration.

7. Serviceberry is not an option in i-Tree Streets. "Other, Broadleaf Deciduous Small" was selected for the calculation.

8. Bald cypress is not an option in i-Tree Streets. Although a deciduous conifer, the nearest option used was "Other, Conifer Evergreen Large".

- Manages approximately 8.3 million gallons or $80 \%$ of annual rainfall on site, equivalent to 13 Olympic-sized swimming pools. 
Figure 1.1: Surface Typology Author: Brandon Zambrano
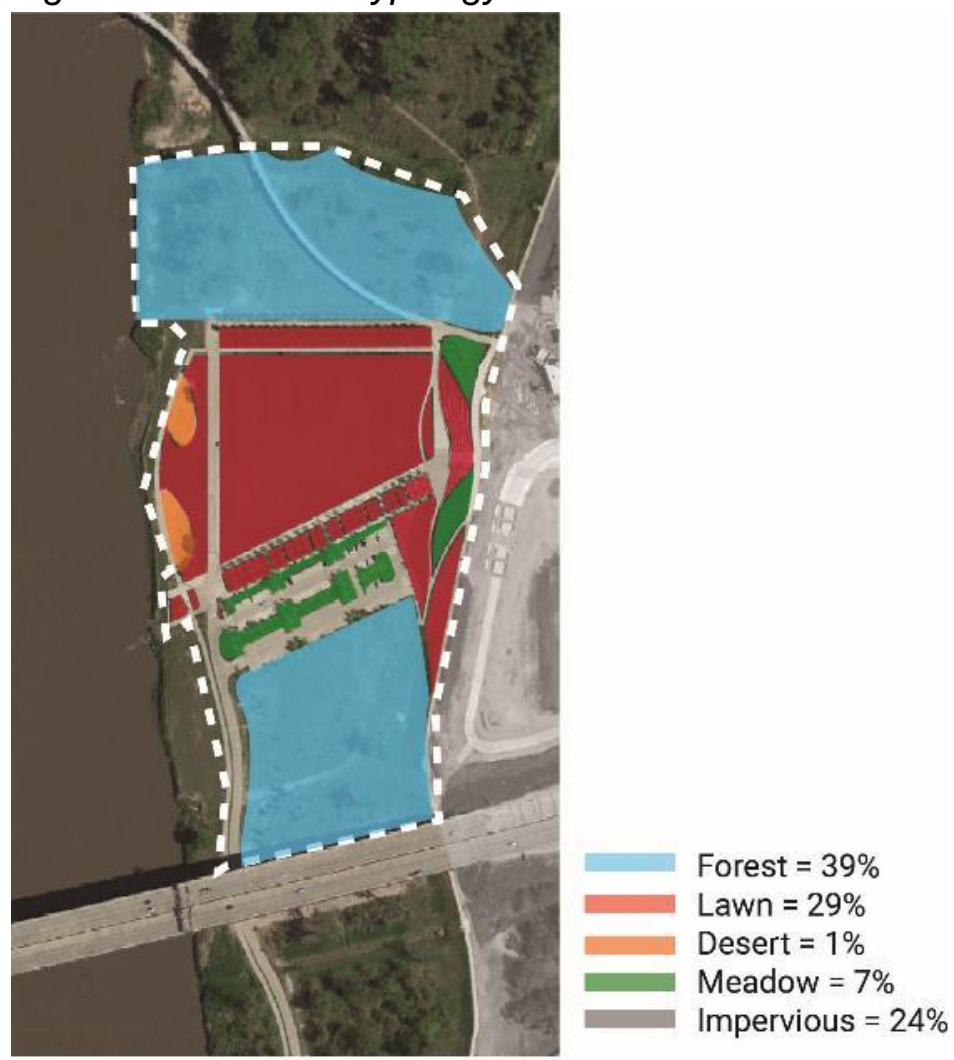

Methods:

Park information and site parameters, which consist of $29 \%$ lawn, $7 \%$ meadow, 39\% forest, $1 \%$ desert, and $24 \%$ impervious surface, were entered into the EPA National Stormwater Calculator to identify the runoff, infiltration, and evaporation percentages based on the estimated annual rainfall (see Appendix B for all specific EPA National Stormwater Calculator entry data and outputs). Additionally, although there are bioswales and bioretention areas that contribute to the project's Best Management Practices, their areas were insignificant when compared to the overall project area; less than $1 \%$ of the total site area. Therefore, this area was not incorporated into the calculation as it was too small to be entered into the calculator and impact the results. To calculate the percent of prevented annual runoff, infiltration and evaporation were added together and multiplied by the amount of annual rainfall to identify how much rainfall will stay on site (see Table 1.3). The amount of prevented runoff was then multiplied by the site size to obtain the cubic-foot value of runoff retained on site per year (see Table 1.4). This value was then converted to gallons of prevented runoff (see Table 1.5). 


\section{Calculations:}

Figure 1.1: EPA National Stormwater Calculator Output

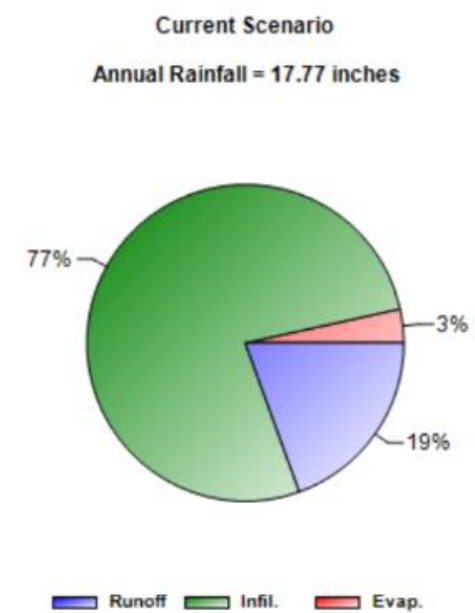

Table 1.3: Prevented Runoff Per Year (ft)

\begin{tabular}{|l|l|l|}
\hline Annual On Site Rainfall & \% of Prevented Runoff & Prevented Runoff (ft) \\
\hline 17.77 inches $=\mathbf{1 . 4 8}$ feet & $77 \%$ (infiltrated) $+3 \%$ (evaporated) $=\mathbf{8 0} \%$ & $(1.48 \mathrm{ft}) \times .8=\mathbf{1 . 1 8 4}$ \\
\hline
\end{tabular}

Table 1.4: Prevented Runoff Per Year (cu ft)

\begin{tabular}{|l|l|l|}
\hline Site Size & Prevented Runoff $(\mathrm{ft})$ & Prevented Runoff $(\mathrm{cu} \mathrm{ft})$ \\
\hline 21.64 acres $=\mathbf{9 4 2 , 6 3 8 . 4} \mathbf{~ s q ~ f t}$ & $(1.48 \mathrm{ft}) \times .8=\mathbf{1 . 1 8 4}$ & $942,638.4 \mathrm{sq} \mathrm{ft} \times 1.184 \mathrm{ft}=\mathbf{1 , 1 1 6 , 0 8 4}$ \\
\hline
\end{tabular}

Table 1.5: Prevented Runoff Per Year (gal)

\begin{tabular}{|l|l|l|}
\hline Prevented Runoff (cu ft) & Conversion & Prevented Runoff (gal) \\
\hline $942,638.4 \mathrm{sq} \mathrm{ft} \times 1.184 \mathrm{ft}=\mathbf{1 , 1 1 6 , 0 8 4}$ & $1 \mathrm{cuft}=7.48 \mathrm{gal}$ & $1,116,084 \times 7.48=\mathbf{8 , 3 4 8 , 3 0 7}$ \\
\hline
\end{tabular}

\section{Sources:}

EPA's National Stormwater Calculator

\section{Limitations:}

1. EPA National Stormwater Calculator inputs such as climate change scenario, site suitability, event threshold, and soil drainage rate were conservatively estimated to ensure a realistic output.

2. The amount of annual rainfall on site is a projected value generated by the EPA National Stormwater Calculator based on inputs such as expected climate change and site location. This is an estimate from the calculator, not a current measured value.

3. The site's green infrastructure (bioretention ponds and bioswales) area totaled less than $1 \%$ of the overall site area. Therefore, these areas were not incorporated into the calculation. 
- Protects 33\% of the area damaged by the 2011 flood (33.7 acres), avoiding an estimated \$16.3 million in damage costs for a major flood event.

Figure 1.2: Flood Safe Zones Author: Brandon Zambrano

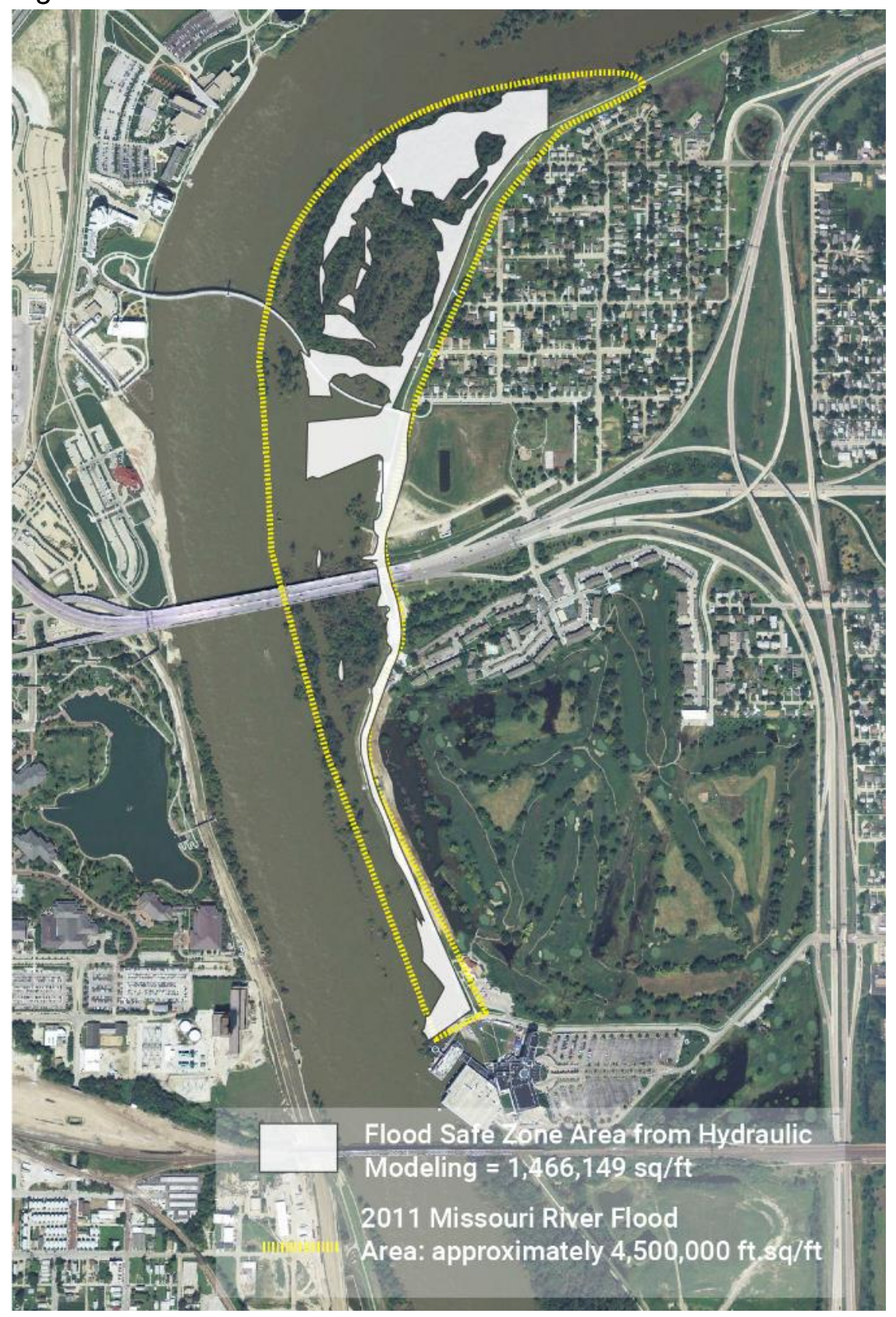

\section{Methods:}

Knowing the high costs of damage in the area after the 2011 flood, the design firm prioritized the integration flood infrastructure to prevent future flood damages in the park. A $\$ 50$ million price tag on the cost of repairs for the area along the levee was obtained from local Council Bluffs news. The Corps of Engineers will not complete repairs to the levee until 2023 due to a lack of funding. 
A protected area boundary was first established using the "Council Bluffs Riverfront: Key Flood Elevations" diagram based on the design firm's hydraulic modeling. Protected area after park reconstruction was divided by the original 2011 flood damaged area along the levee to obtain the percent of total damaged area now protected. Areas were measured using Google Earth Pro (see Table 1.6). This percentage was then multiplied by the damage cost in the $2011 \mathrm{flood}$ along the levee to determine the cost saved in damage repairs in the event of another similar size flood event (see Table 1.7).

\section{Calculations:}

Table 1.6: Percent of Flood Damaged Area Turned Into Flood Protected Area

\begin{tabular}{|l|l|l|}
\hline Area Damaged by 2011 Flood Along the Levee (sq ft) & $\begin{array}{l}\text { Estimated Area Damaged in 2011 Flood Now } \\
\text { Protected After Park Construction (sq ft) }\end{array}$ & \% of Total Damaged Area Now Protected \\
\hline $4,500,000$ & $1,466,149$ & $1,466,149 / 4,500,000=.32581=\mathbf{3 2 . 5 8 \%}$ \\
\hline
\end{tabular}

Table 1.7: Savings in Damage Cost

\begin{tabular}{|l|l|l|}
\hline Cost of Damage by 2011 Flood Along the Levee & \% of Total Damaged Area Now Protected & $\begin{array}{l}\text { Cost Saved in Damage Repairs in the Event of } \\
\text { Another Flood After Reconstruction }\end{array}$ \\
\hline$\$ 50$ million & $32.58 \%$ & $\$ 50,000,000 \times .3258=\$ 16,290,000$ \\
\hline
\end{tabular}

\section{Sources:}

Google Earth Pro

Leu, Jon. 2017. "Continuation of Levee Repairs Waiting on Corps of Engineers," Nonpareil

Online.

https://www.nonpareilonline.com/news/region/continuation-of-levee-repairs-waiting-oncorps-of-engineers/article 31da5e18-aa26-11e7-ae92-1fd39398ece3.html

Sasaki Associates. "Council Bluffs Riverfront: Key Flood Elevations." https://drive.google.com/file/d/1w1Vq3mMu1yVwaEJyFWLmVB4hSPBaf1Z3/view

\section{Limitations:}

1. Land value in the adjacent area may have increased, resulting in a higher damage cost if affected by flood.

2. Measurements obtained via Google Earth Pro are not $100 \%$ accurate and are subject to human error, but provide a basis for comparison

3. Hydraulic modeling scenarios are projective, hypothetical, and not $100 \%$ accurate. Actual factors and influences will likely change over time

\section{Social Benefits}

\section{- Increases levels of outdoor activity for $68 \%$ of 47 surveyed users.}




\section{Methods:}

Users were asked to select which phrases correspond to Tom Hanafan River's Edge Park (all that apply). Surveys were distributed to both concert goers on event days and park users on typical days.

\section{Calculations:}

Figure 2.1: Level of Outdoor Activity Results

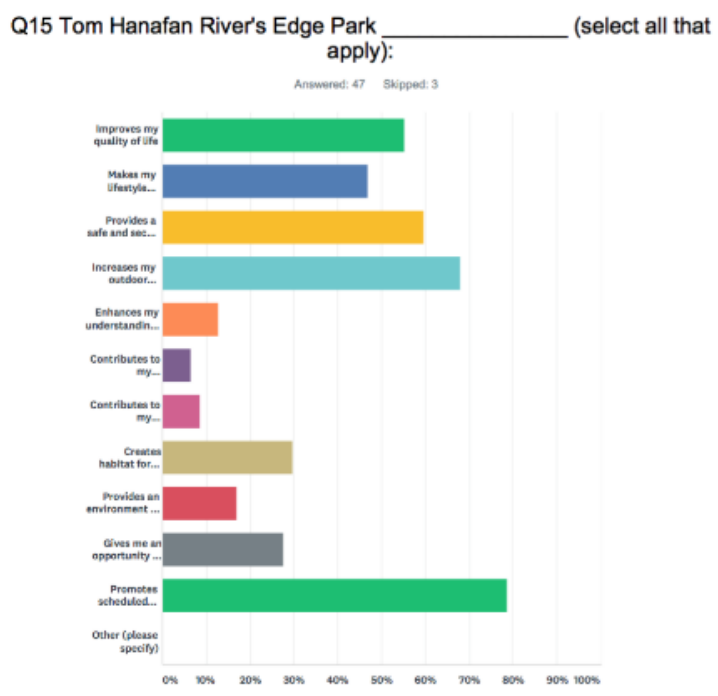

Author: SurveyMonkey

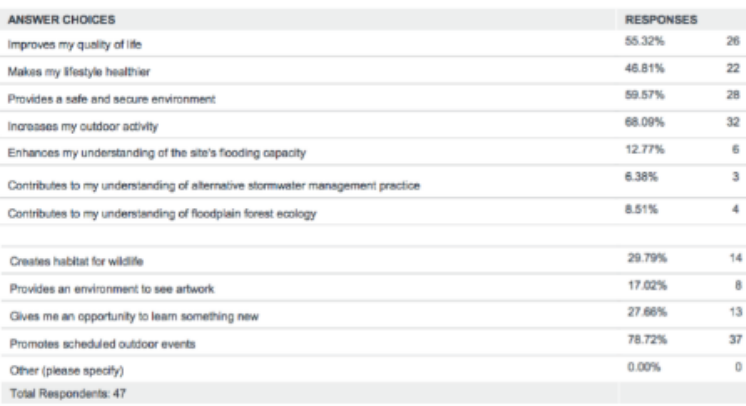

Table 2.1: Increased Level of Outdoor Activity

\begin{tabular}{|l|l|l|}
\hline Response & Responses (\%) & Responses (\#) \\
\hline "Increases outdoor activity" & 68.09 & 32 \\
\hline & & Total Responses: 47 \\
\hline
\end{tabular}

Sources:

Survey Question \#15 under “About You” (see Appendix A)

\section{Limitations:}

1. Although this survey was distributed to both event visitors and average day park users, visitors on-site for a concert or event may have different responses than those who frequent the park on a daily basis or are familiar with the limited site access prior to the park's construction.

2. Because Tom Hanafan River's Edge Park doesn't have frequent visitors on a day to day basis, it was difficult to get responses from a large number of users. The sampling size for survey distribution was 50 . Not all participants answered each question.

\section{- Improves perception of safety for $84 \%$ of 37 surveyed users.}




\section{Methods:}

Previously a woodland with an unsafe feeling and ATV usage, Tom Hanafan River's Edge Park provides an organized, accessible public space for dog walkers, athletes, concert goers, and families. Users were asked about the park's effect on their sense of safety on-site via survey. Surveys were distributed to both concert goers on event days and park users on typical days.

\section{Calculations:}

Figure 2.2: Perception of Safety Results Author: SurveyMonkey

Q24 Do you feel safer and more comfortable using Tom Hanafan River's

Edge Park at all times of the day after the reconstruction? How much safer and more comfortable?
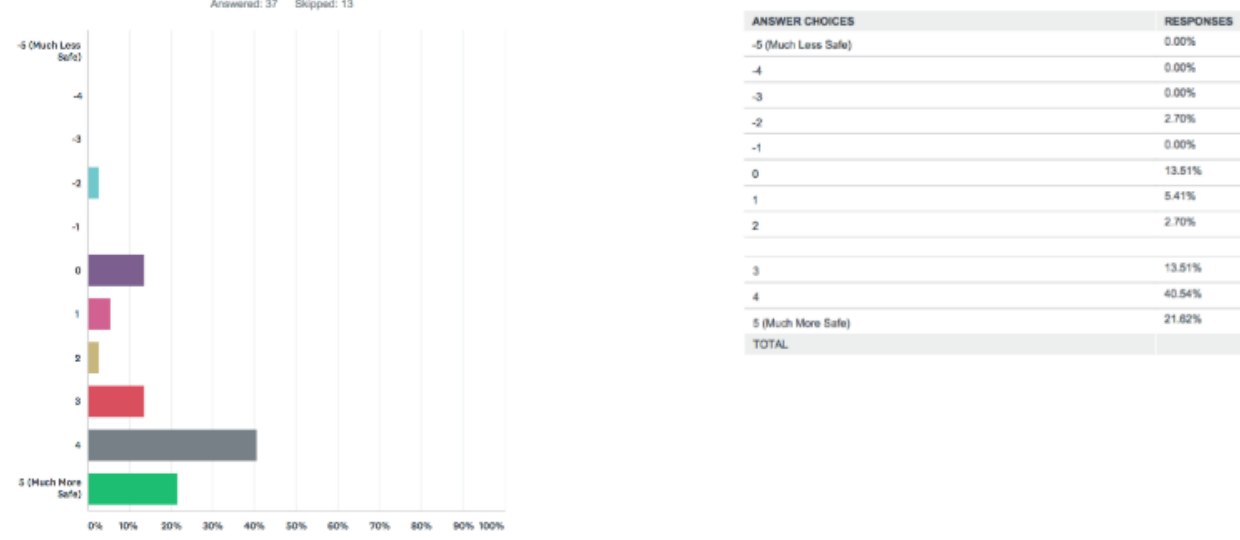

Table 2.2: Level of Safety Ratings

\begin{tabular}{|l|l|l|}
\hline Answer Choice & Responses (\%) & Responses (\#) \\
\hline-5 (Much Less Safe) & 0.00 & 0 \\
\hline-4 & 0.00 & 0 \\
\hline-3 & 0.00 & 0 \\
\hline-2 & 2.70 & 1 \\
\hline-1 & 0.00 & 0 \\
\hline 0 & 13.51 & 5 \\
\hline 1 & 5.41 & 2 \\
\hline 2 & 2.70 & 1 \\
\hline 3 & 13.51 & 5 \\
\hline 4 & 40.54 & 15 \\
\hline 5 (Much More Safe) & 21.62 & 8 \\
\hline & & Total: 37 \\
\hline
\end{tabular}

Table 2.3: Increased Safety Responses

\begin{tabular}{|l|l|}
\hline "Safer" Range Answers & Response (\%) \\
\hline 1 & 5.41 \\
\hline
\end{tabular}




\begin{tabular}{|l|l|}
\hline 2 & 2.70 \\
\hline 3 & 13.51 \\
\hline 4 & 40.54 \\
\hline 5 & 21.62 \\
\hline & Total “Safer” Responses: 83.78 \\
\hline
\end{tabular}

Sources:

Survey Question \#6 under "Access \& Safety” (see Appendix A)

\section{Limitations:}

1. Although this survey was distributed to both event visitors and average day park users, visitors on-site for a concert or event may have different responses than those who frequent the park on a daily basis or are familiar with safety issues prior to the park's construction.

2. Because Tom Hanafan River's Edge Park doesn't have frequent visitors on a day to day basis, it is difficult to get responses from a large number of users. The sampling size for survey distribution was 50 . Not all participants answered each question.

- Increases ease of access to the Missouri River according to $89 \%$ of 35 surveyed users.

Methods:

Previously a woodland without public access to the river, Tom Hanafan River's Edge Park opens up a section of the riverfront to the public. Users were asked about the park's impact on their access to the Missouri River via on-site survey. Surveys were distributed to both concert goers on event days and park users on typical days. 


\section{Calculations:}

Figure 2.3: Ease of Access Results Author: SurveyMonkey

Q23 Do you find access to the Missouri river from Tom Hanafan River's
Edge Park easier or more difficult after the reconstruction? How much

easier or more difficult?
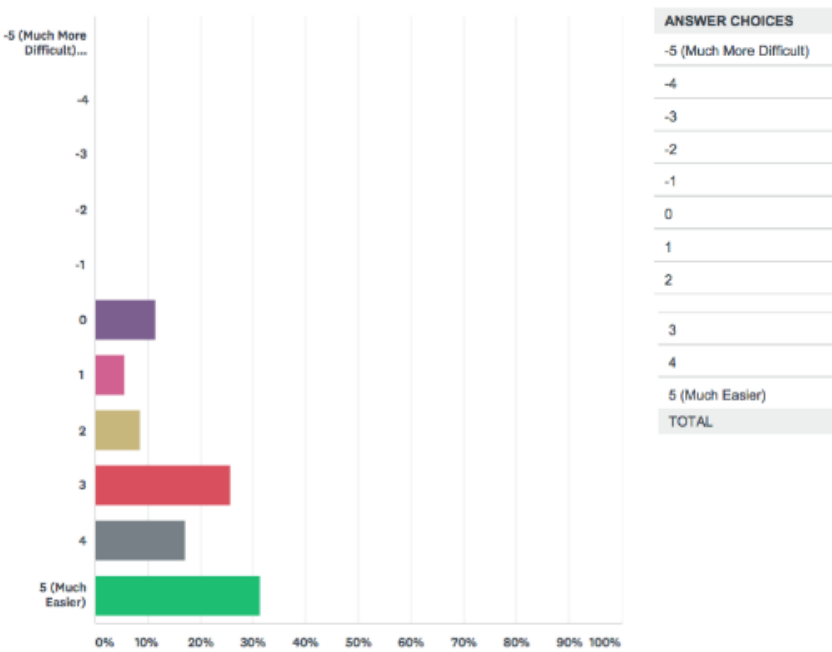

Table 2.4: Ease of Access to the Missouri River Responses

\begin{tabular}{|l|l|l|}
\hline Answer Choice & Responses (\%) & Responses (\#) \\
\hline-5 (Much More Difficult) & 0.00 & 0 \\
\hline-4 & 0.00 & 0 \\
\hline-3 & 0.00 & 0 \\
\hline-2 & 0.00 & 0 \\
\hline-1 & 0.00 & 0 \\
\hline 0 & 11.43 & 4 \\
\hline 1 & 5.71 & 2 \\
\hline 2 & 8.57 & 3 \\
\hline 3 & 25.71 & 9 \\
\hline 4 & 17.14 & 6 \\
\hline 5 (Much Easier) & 31.43 & 11 \\
\hline & & Total: 35 \\
\hline
\end{tabular}

Table 2.5: Increased Ease of Access to the Missouri River Responses

\begin{tabular}{|l|l|}
\hline “Easier” Range Answers & Response (\%) \\
\hline 1 & 5.71 \\
\hline 2 & 8.57 \\
\hline 3 & 25.71 \\
\hline
\end{tabular}




\begin{tabular}{|l|l|}
\hline 4 & 17.14 \\
\hline 5 & 31.43 \\
\hline & Total “Easier" Responses: 88.56\% \\
\hline
\end{tabular}

Sources:

Survey Question \#5 under "Access \& Safety" (see Appendix A)

Limitations:

1. Although this survey was distributed to both event visitors and average day park users, visitors on-site for a concert or event may have different responses than those who frequent the park on a daily basis or are familiar with the limited site access prior to the park's construction.

2. Because Tom Hanafan River's Edge Park doesn't have a large number of visitors on a day to day basis, it is difficult to get responses from a large number of users. The sampling size for survey distribution was 50 . Not all participants answered each question.

\section{Economic Benefits}

- Generated \$365,217 in revenue for the City of Council Bluffs between June 2015 and May 2017 through the park's annual LoessFest, which attracts over 100,000 attendees each year.

Methods:

LoessFest is an annual outdoor festival consisting of musical acts, food trucks, and fireworks on the lawn of Tom Hanafan River's Edge Park at the end of May (LoessFest, 2018). LoessFest has been awarded the 2017 Outstanding Event Award by the lowa Tourism Department for the quality and success as well as the Gold Citation of Excellence in 2015 presented by the American Marketing Association for the success of Loessfest in 2014 (The City of Council Bluffs, 2017).

Data was obtained from the City of Council Bluffs in their Fiscal Year 2017 Budget to Actual Revenue Comparison chart on pg. 43 of the City Council Agenda (The City of Council Bluffs City Council, 2017) which records the yearly revenue contributed by LoessFest. Fiscal year 16/17 revenue at May 31, 2017 was $\$ 129,217$ and fiscal year 15/16 revenue at May 31, 2016 was $\$ 236,000$. Both these values were added together for total revenue provided from Loessfest for 2016 and 2017. The number of Loessfest attendees since its 2013 establishment was pulled from the LoessFest official website (LoessFest, 2018).

\section{Calculations}


Table 3.2: Loessfest Revenue Yield 2016 and 2017

\begin{tabular}{|l|l|l|}
\hline YTD (05/31/2017) & YTD (05/31/2016) ${ }^{1}$ & Total Revenue Yield 2016 \& 2017 \\
\hline$\$ 129,217$ & $\$ 236,000$ & Total:\$129,217+\$236,000=\$365,217 \\
\hline
\end{tabular}

Sources:

The City of Council Bluffs City Council. 2017. "Council Agenda, City of Council Bluffs, lowa Regular Meeting June 26, 2017, 7:00 PM Council Chambers, 2nd Floor, City Hall 209 Pearl Street," The City of Council Bluffs, IA. http://www.councilbluffs-ia.gov/AgendaCenter/ViewFile/Agenda/ 06262017 1604

The City of Council Bluffs. 2017. "Awards and Recognitions," The City of Council Bluffs. http://www.councilbluffs-ia.gov/2148/Awards-Recognitions

LoessFest. 2018. "About LoessFest," lowa West Foundation and The City of Council Bluffs.

http://loessfest.com/about/

\section{Limitations:}

1. LoessFest revenue was publicly recorded by the City of Council Bluffs for only 2016 and 2017. LoessFest began in 2013.

2. Although many attendees of Loessfest were brought to Tom Hanafan River's Edge Park solely because of the festival, there is overlap between those that repeatedly visit the park and those that only attend Loessfest.

3. The 2017 Loessfest revenue yield was a little over half of the 2016 revenue. The cause for this reduction in revenue is unknown. Factors such as weather could have played a significant role.

- Catalyzed approximately $\$ 460$ million in public and private development within a half-mile radius since 2011. 

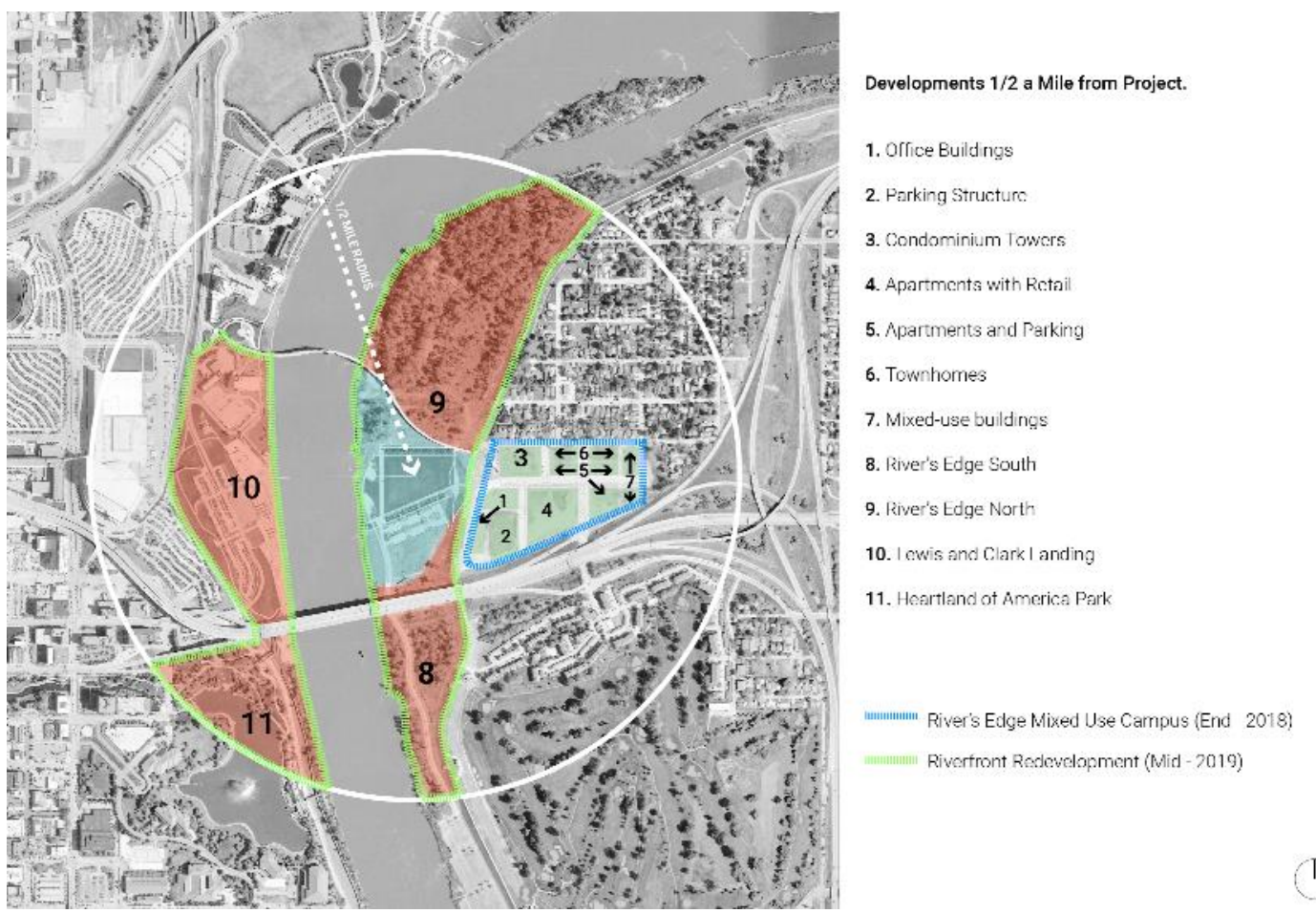

Methods:

The redevelopment of Tom Hanafan River's Edge Park is credited as a catalyst for multiple private and public investments along the Council Bluffs and nearby Omaha riverfront (Riverfront Revitalization Project, 2018). The amount of public and private investments pre- and postproject are compared to reveal an estimated increase in development.

Since 2011, only one major project was completed-Tom Hanafan River's Edge Park. There are two major developments each that are in the process of being developed adjacent to the park; River's Edge Mixed Use Campus and Omaha's Riverfront Development (see Figure 3.1). Referencing local news articles, estimated investments were recorded (see Table 3.1). Various companies will be moving into the area such as Pillar Technology which will occupy $8000 \mathrm{sq} / \mathrm{ft}$ in the first office building of the mixed use campus. The company plans to commit 30 new fulltime IT positions and move to buildings third floor by 2019. Inspection of aerial images using Google Earth Pro confirmed no other new development (other than the Mixed Use Campus and Omaha Riverfront) after the construction of Tom Hanafan River's Edge Park.

\section{Calculations:}

Table 3.1: Redevelopment Investments

\begin{tabular}{|l|l|l|}
\hline Riverfront Redevelopment (Omaha, NE) & $\begin{array}{l}\text { River's Edge Mixed Use Campus (Council Bluffs, IA) } \\
\text { Developers: Noddle Cos. \& lowa West Foundation }\end{array}$ & Total \\
\hline Total Investment: 290 Million & Total Investment: 170 Million & Total Investment: 460 million \\
\hline
\end{tabular}


Sources:

AIM. 2018. "Pillar Technology Coming to Council Bluff's Rivers' Edge Development," AIM Career Link. https://careerlink.com/careerhub/pillar-technology-coming-to-council-bluffs-rivers-edge -development/

Gonzalez, Cindy. 2017. "Flurry of Construction Projects at River's Edge Leads to Creation of 'a New Front Door to Council Bluffs,"' Omaha World Herald.

http://www.omaha.com/money/flurry-of-construction-projects-at-river-s-edge-leads-to/a rticle ae6fac05-18df-59e1-8f35-032b611fa03d.html

Moselle. 2018. “Living at the Edge," Moselle at River's Edge.

http://moselleriversedge.com

Nohr, Emily and Cindy Gonzalez. 2018. "\$290 Million Plan for Omaha Riverfront Draws

Praise, But Some Like Gene Leahy Mall as it is," Omaha World Herald.

http://www.omaha.com/money/flurry-of-construction-projects-at-river-s-edge-leads-to/a rticle ae6fac05-18df-59e1-8f35-032b611fa03d.html

Riverfront Revitalization Project. 2018. "Creating a Catalyst on the Riverfront," Riverfront Revitalization Project

http://riverfrontrevitalization.com

Limitations:

1. This project has affected development in both Council Bluffs and Omaha. Utilizing records from two separate cities, the data is based on estimates reported, not actual costs as these developments are in progress.

2. Other external factors may have contributed to new development nearby, such as population growth.

\section{Cost Comparison}

- Although the integrated meadow's upfront cost of $\$ 29,600$ was $\$ 1$ more per sf than conventional turfgrass, which would have cost $\$ 9,900$, the cost for annual landscape maintenance on a meadow is 3.85 times less than the care of a traditional mown lawn. In 5 years, savings on maintenance will surpass the premium paid to install the meadow, and the park will save $\$ 4,700$ every year thereafter.

Methods:

In correspondence with both the design firm and The City of Council Bluff's Maintenance Staff, data was collected on site size, install costs, and maintenance costs. Tom Hanafan River's Edge Park has a planted meadow that is $19,711 \mathrm{sf}$, or 0.45 acres. This area was considered for either lawn or meadow during the design phase. Because meadows require only 1 annual mow (Pennsylvania Land Trust Association, 2017), the cost of mowing the meadow was calculated 
by multiplying the site size by the cost of mowing per acre. For turf, it was assumed that it would be mowed once per week for 26 weeks of the year in the Council Bluffs climate (The Conservation Foundation). Therefore, the cost of mowing was multiplied by 26 to obtain this value. Since turf requires weekly watering for all 26 weeks using $1 \mathrm{gal} / \mathrm{sq} \mathrm{ft}$ at $\$ 0.004$ (The City of Council Bluffs Water Works), the total cost of the site's weekly gallon requirements was multiplied by 26 weeks (see Table A, row 1). Other annual expenses to maintain turf grass consists of fertilizer ( $\$ 0.01$ per sf), grub control ( $\$ 0.006$ per sf), aeration ( $\$ 0.008$ per sf), and repairs (\$0.02 per sf), which adds an additional cost of $\$ 0.04$ per sf for lawn maintenance (The Conservation Foundation). In comparison, additional annual meadow expenses consist of herbicide treatments ( $\$ 0.02$ per sf) and controlled-burning management every 3-4 years $(\$ 0.015$ per sf), which can vary year by year (The Conservation Foundation). However, average additional costs were obtained from The Conservation Foundation and are recorded as "Extras" Cost (see Table A, row 2). Combined with the annual mowing and watering costs, the total annual costs of both turf and meadow were obtained (see Table A, row 2).

Provided by the design firm, the cost of install per sq $\mathrm{ft}$ (including material and labor) for each condition was multiplied by the site area. The difference between these two costs was then identified (see Table B), as well as the difference factor between turf and meadow for annual maintenance (see Table C). Finally, The breakeven point was found to determine when savings on meadow maintenance would surpass the turf install and maintenance fees. Annual maintenance fees were added to the initial installation costs of each material to determine at what year would it break even (see Table D).

\section{Calculations:}

Table A: Annual Maintenance Costs

\begin{tabular}{|c|c|c|c|c|}
\hline Meadow Or Turf Area ${ }^{1}$ & Cost of Mowing Per Acre ${ }^{2}$ & $\begin{array}{l}\text { Cost of Mowing a Meadow } \\
\text { Per Year } \\
\text { (1 Occurrence) }\end{array}$ & $\begin{array}{l}\text { Cost of Mowing Turf Per } \\
\text { Year } \\
\text { (26 Occurrences) }\end{array}$ & $\begin{array}{l}\text { Annual Turf Watering Cost : } \\
\text { (1 gallon/ sq. ft at } \$ 0.004^{3} \text { for } \\
26 \text { weeks) }\end{array}$ \\
\hline $19,711 \mathrm{sq} f t=0.45$ acres & $\$ 185$ & 0.45 acres $\times \$ 185=\$ 83.25$ & $\$ 83.25 \times 26=\$ 2, \mathbf{1 6 4 . 5 0}$ & $\begin{array}{l}19,711 \text { gal } \times \$ .004=\$ 78.84 \times \\
26 \text { weeks }=\$ 2,050\end{array}$ \\
\hline $\begin{array}{l}\text { Annual Turf Maintenance } \\
\text { "Extras" " Cost }{ }^{2}\end{array}$ & $\begin{array}{l}\text { Annual Meadow } \\
\text { Maintenance "Extras", Cost }{ }^{2}\end{array}$ & $\begin{array}{l}\text { Total Annual Additional Cost } \\
\text { of Turf }\end{array}$ & $\begin{array}{l}\text { Total Annual Additional Cost } \\
\text { of Meadow }\end{array}$ & $\begin{array}{l}\text { Difference of Turf and } \\
\text { Meadow Annual Costs }\end{array}$ \\
\hline$\$ 2,075$ & $\$ 1,550$ & $\begin{array}{l}\$ 2,075+\$ 2,050,+\$ 2,164.50 \\
=\$ 6,289.50\end{array}$ & $\$ 83.25+1,550=\$ 1,633.25$ & $\begin{array}{l}\$ 6,289.50-\$ 1,633.25= \\
\$ 4,656.25\end{array}$ \\
\hline
\end{tabular}

2 Source: The Conservation Foundation

3 Source: The City of Council Bluffs Water Works

4 "Extras" include fertilizer, grub control, aeration, herbicide treatments, and burn management. (The Conservation Foundation)

Table B: Labor and Install Costs

\begin{tabular}{|l|l|l|l|l|}
\hline $\begin{array}{l}\text { Initial Cost of Meadow Install } \\
\text { Per sq ft (Seed and Labor) }{ }^{1:}\end{array}$ & $\begin{array}{l}\text { Initial Cost of Meadow Install } \\
\text { (Seed and Labor): }\end{array}$ & $\begin{array}{l}\text { Initial Cost of Lawn Install } \\
\text { Per sq ft (Sod and Labor) }\end{array}$
\end{tabular}




\begin{tabular}{|l|l|l|l|l|}
\hline & $\$ 29,566.50$ & & & $\$ 19,711$ \\
\hline
\end{tabular}

Table C: Annual Maintenance Difference Factor

\begin{tabular}{|l|l|l|}
\hline $\begin{array}{l}\text { Total Annual Additional Cost of Turf for } \\
\text { Maintenance }\end{array}$ & $\begin{array}{l}\text { Total Annual Additional Cost of Meadow for } \\
\text { Maintenance }\end{array}$ & $\begin{array}{l}\text { X Times Less Expensive Annually to Maintain } \\
\text { Meadow }\end{array}$ \\
\hline$\$ 2,075+\$ 2,050,+\$ 2,164.50=\$ 6,289.50$ & $\$ 83.25+1,550=\$ 1,633.25$ & $\$ 6,289.50 / \$ 1,633.25=\mathbf{3 . 8 5 x}$ \\
\hline Cost per sq ft: $\$ 6,289.50 / 19,711 \mathrm{sq} \mathrm{ft}=\$ 0.32$ & Cost per sq ft: $\$ 1,633.25 / 19,711 \mathrm{sq} \mathrm{ft}=\$ .08$ & Cost per sq ft Differene: $\$ 0.32-\$ .08=\$ 0.24$ \\
\hline
\end{tabular}

Table D: Breakeven Point

\begin{tabular}{|l|l|l|l|l|l|l|}
\hline & Initial Cost & Total Cost After Yr. 1 & Total Cost After Yr. $\mathbf{2}$ & Total Cost After Yr. $\mathbf{3}$ & Total Cost After Yr. $\mathbf{4}$ & Total Cost After Yr. $\mathbf{5}$ \\
\hline Turf & $\$ 9,855.50$ & $\$ 16,145.00$ & $\$ 22,434.50$ & $\$ 28,724.00$ & $\$ 35,013.50$ & $\$ \mathbf{4 1 , 3 0 3 . 0 0}$ \\
\hline Meadow & $\$ 29,566.50$ & $\$ 31,199.75$ & $\$ 32,833$ & $\$ 34,466.25$ & $\$ 36,099.50$ & $\$ 37,732.75$ \\
\hline
\end{tabular}

1 The annual maintenance cost is added to the initial cost each year

Sources:

Sasaki Associates

The City of Council Bluffs Water Works

https://www.cbwaterworks.com/devandcontractor/installationspecs.aspx

The Conservation Foundation. "The Conservation Foundation's Pollinator Meadow Mix," The Conservation Foundation.

http://www.theconservationfoundation.org/images/Meadow\%20Mix\%20Brochure\%20

FINAL\%202.19.15.pdf

Pennsylvania Land Trust Association. 2017. "From Lawn to Meadow," Pennsylvania Land Trust

Association.

https://conservationtools.org/guides/151-from-lawn-to-meadow

Limitations:

1. Annual turf grass expenses consisting of fertilizer, grub control, aeration, and repairs along with annual meadow expenses of herbicide treatments and burn management vary year by year due to the extent in which they are needed. Therefore, the values reported in Table 1 under Annual "Extras" cost are averages obtained from The Conservation Foundation.

2. Cost of an irrigation system and install was not included in this calculation.

\section{Appendix A: Survey Questions and Results}

\section{TOM HANAFAN RIVER'S EDGE PARK USER SURVEY}

$\partial \quad$ By selecting this box, I agree to participate in this survey and am aware that my personal information will not be collected. 


\section{ABOUT YOU}

- $\quad$ Select one of the following as your best descriptor

- I am a local from (please indicate your community/neighborhood)

- I'm visiting from out of town

- How far do you travel to Tom Hanafan River's Edge Park?

- Less than 1 mile

- 1-2 miles

- 3-5 miles

- More than 5 miles

- If given the opportunity, would you like to live closer to Tom Hanafan River's Edge Park?

- Yes

- No

- Maybe

- Select your age group:

- 18-25

○ 26-35

○ $36-45$

○ 46-55

○ 56-65

○ 65+

- What time of day do you typically visit Tom Hanafan River's Edge Park? (select all that apply)

- Early Morning: 6am-10am

- Late Morning: 10am-12pm

- Early Afternoon: 12pm-2pm

- Late Afternoon: $3 \mathrm{pm}-5 \mathrm{pm}$

- Evening: $5 \mathrm{pm}-7 \mathrm{pm}$

- Night: 8pm-12am

O Other:

- On average, how often do you visit Tom Hanafan River's Edge Park?

- Everyday

- Several times a week

- About once a week

- About once a month

- Once every six months

- Once a year or less

- Don't know, this is my first visit

- How do you usually arrive to the park?

- On foot

- By bicycle

- By car

- By public transportation

- When you visit Tom Hanafan River's Edge Park, how long do you usually stay?

- 15 minutes or less

- Half hour

○ 1-2 hours

○ 3+ hours

- Other:

- What do you think of when you think of Tom Hanafan River's Edge Park 
- Connection to the Pedestrian Bridge

- Place for recreation and events

- Access to Missouri River

- See and be seen spot/people watching

O Other

- How would you rate the appearance of Tom Hanafan River's Edge Park today?

- Very good

- Good

- Neutral

- Poor

- Very Poor

- Why did you give Tom Hanafan River's Edge Park this rating?

- If neutral or less, what would improve your perception of Tom Hanafan River's Edge Park?

- My motivation for visiting Tom Hanafan River's Edge Park is to...(select all that apply)

- Run

- Other exercise and fitness activities

o Walk

○ Bike

- Attend events

- Play/bring my children

- Access the water

- Connect to Omaha via the pedestrian bridge

- Enjoy nature and be outdoors

- Socialize with friends and family

- Reduce Stress

O Other:

- What activities do you participate in while visiting Tom Hanafan River's Edge Park?

- Walking

$\circ \quad$ Jogging/running

○ Walking dog

- Plant/wildlife viewing

$\circ \quad$ Picnicking/eating

- Sledding or other winter activities (please specify)

- Cycling

- Play time with my children

- Relaxing

- Outdoor education

- Community events

- Other: (please specify)

- Tom Hanafan River's Edge Park (select all that apply):

- Improves my quality of life

- Makes my lifestyle healthier

- Provides a safe and secure environment

- Increases my outdoor activity

- Enhances my understanding of the site's flooding capacity

- Contributes to my understanding of alternative stormwater management practice

- Contributes to my understanding of floodplain forest ecology 
- Creates habitat for wildlife

- Provides an environment to see artwork

- Gives me an opportunity to learn something new

- Promotes scheduled outdoor events

- Have you ever attended an event held in Tom Hanafan River's Edge Park?

- Yes

- No

- If you answered no, would you be interested in attending an event if it is held in Tom Hanafan

River's Edge Park?

○ Yes

- No

- Maybe

- What types of events would you like to see take place at Tom Hanafan River's Edge Park?

\section{ACCESS \& SAFETY}

- Within the Tom Hanafan River's Edge Park, I feel the quantity of parking is...

- Sufficient

- Should be reduced

- Should be increased

- Should be increased in the form of parking garages

- I don't know.

- How would you rate your satisfaction with the amount of bike parking in Tom Hanafan River's Edge Park?

○ Very good

- Good

- Neutral

- Poor

- Very Poor

- I feel safe and comfortable using Tom Hanafan River's Edge Park at all times of the day.

- Strongly agree

- Agree

- Neutral

- Disagree

- Strongly Disagree

- Other:

- Are you familiar with what Tom Hanafan River's Edge Park looked like before it became a public park?

○ Yes

- No

If you answered "Yes," please continue to fill out the following questions. If you answered "No," please skip to the next section titled "ENVIRONMENTAL BENEFITS"

- Do you find access to the Missouri river from Tom Hanafan River's Edge Park easier or more difficult after the reconstruction? How much easier or more difficult?
(Much More Difficult) - 5
$-4 \quad-3$

- Do you feel safer and more comfortable using Tom Hanafan River's Edge Park at all times of the day after the reconstruction? How much safer and more comfortable?

$\begin{array}{llllllllllll}\text { (Less Safe) } & -5 & -4 & -3 & -2 & -1 & 0 & 1 & 2 & 3 & 4 & 5 \\ \text { (Much Safer) }\end{array}$ 


\section{ENVIRONMENTAL BENEFITS}

- $\quad$ Are you aware that the park contributes to the flood resiliency of Council Bluffs?

- Yes

○ No

- Maybe

- If not, would you like to learn more?

- Yes

- No

- Maybe

- What new ways could Tom Hanafan River's Edge Park educate those about the environmental benefits that the site offers to the community?

- Pamphlet

- Signs

- Art Piece

- Events

- Other

- Do the ecological restoration and flood control benefits influence your desire to come visit the park?

- Yes

- No

\section{Selected Survey Results}

Tom Hanafan River's Edge User Survey

Q1 Select one of the following as your best descriptor

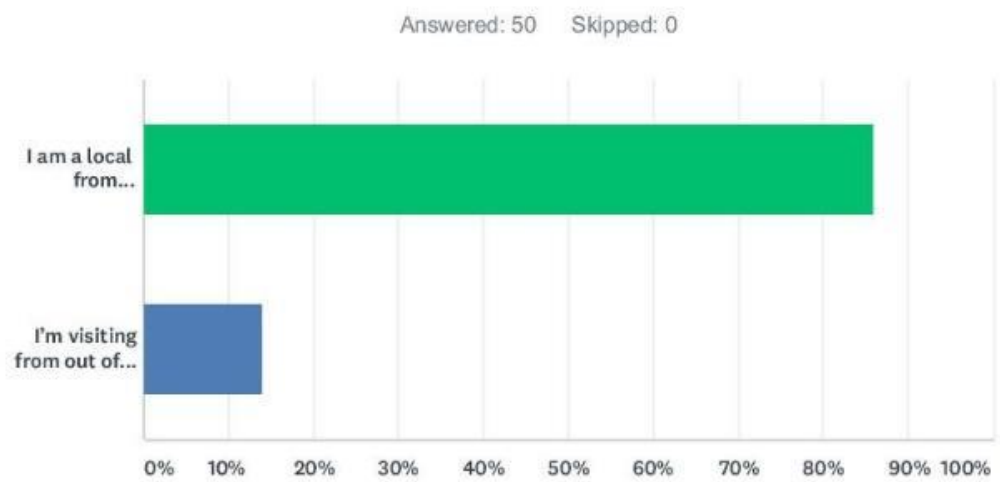

\section{ANSWER CHOICES}

I am a local from

I'm visiting from out of town

TOTAL

\begin{tabular}{|lr}
\hline RESPONSES & \\
\hline $86.00 \%$ & 43 \\
\hline $14.00 \%$ & 7 \\
& 50 \\
\hline
\end{tabular}


Q2 How far do you travel to Tom Hanafan River's Edge Park?

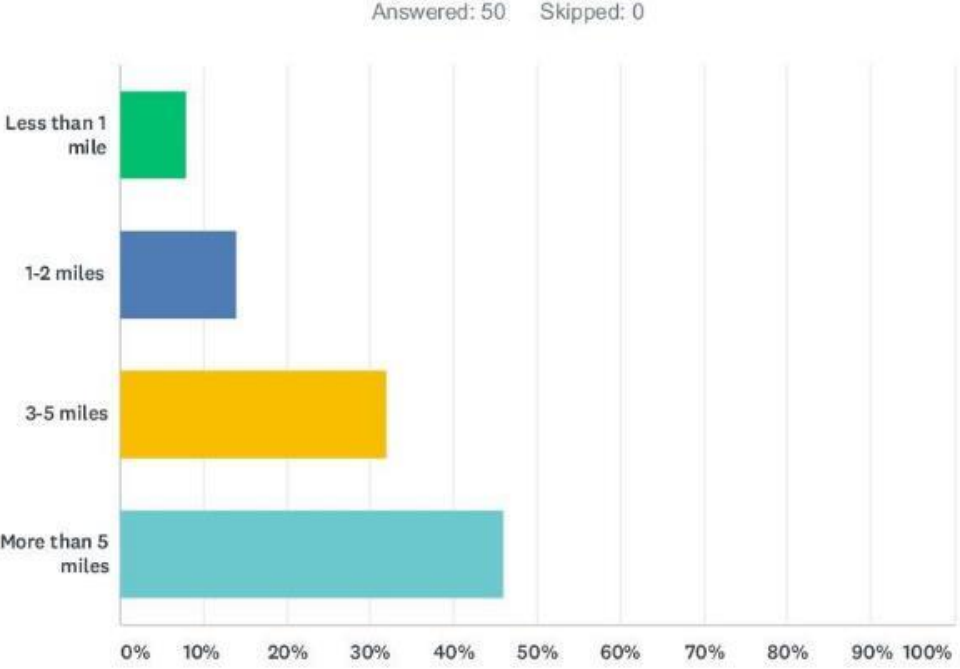

\begin{tabular}{|c|c|c|}
\hline ANSWER CHOICES & RESPONSES & \\
\hline Less than 1 mile & $8.00 \%$ & 4 \\
\hline $1-2$ miles & $14.00 \%$ & 7 \\
\hline 3-5 miles & $32.00 \%$ & 16 \\
\hline More than 5 miles & $46.00 \%$ & 23 \\
\hline TOTAL & & 50 \\
\hline
\end{tabular}

Q3 If given the opportunity, would you like to live closer to Tom Hanafan River's Edge Park?

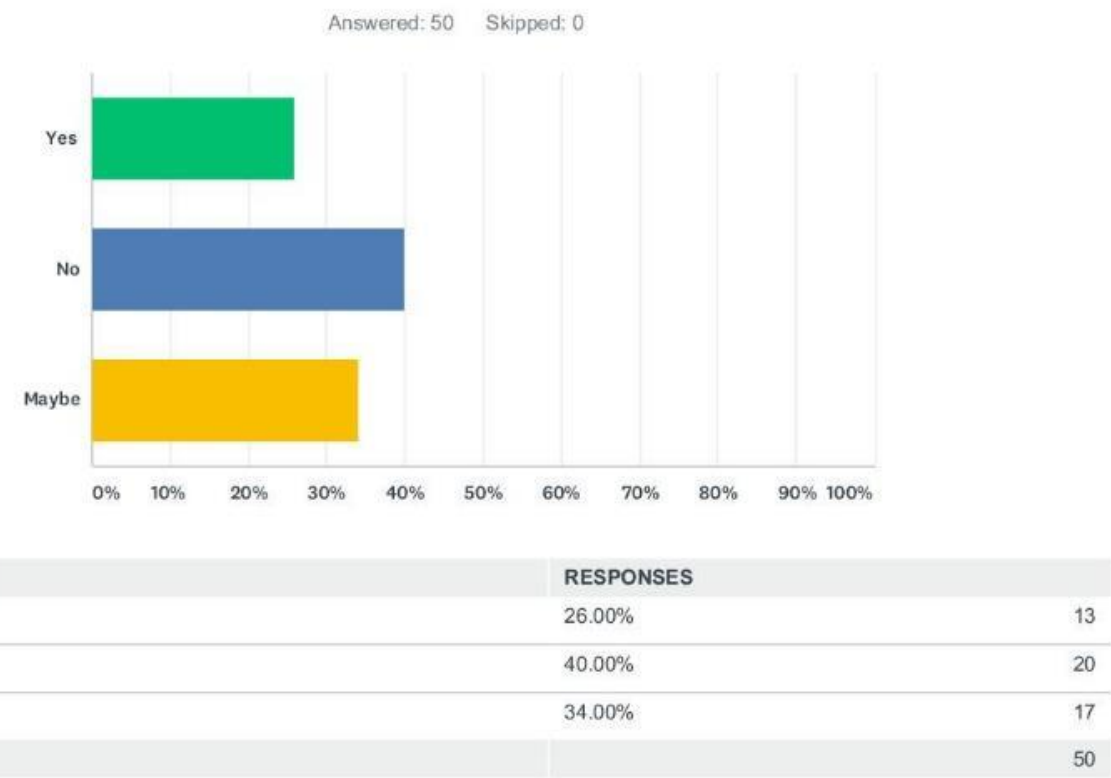




\section{Q4 Select your age group:}

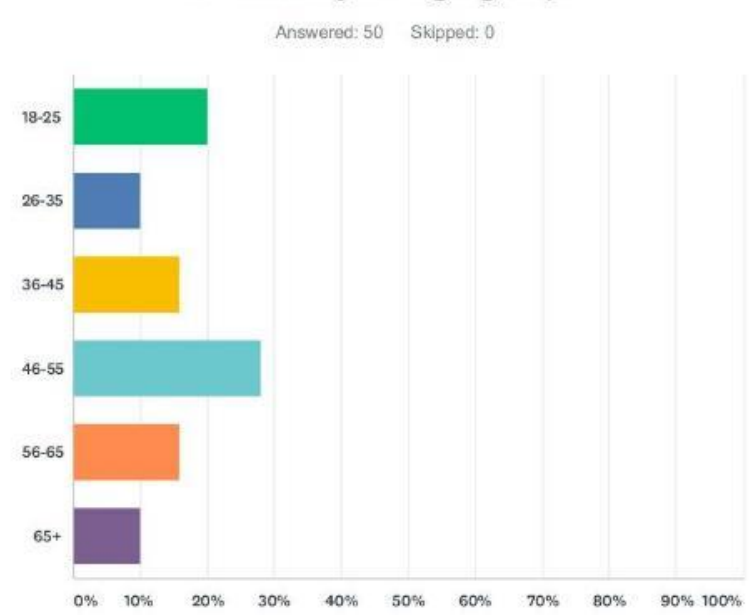

\begin{tabular}{llr} 
ANSWER CHOICES & RESPONSES & 10 \\
\hline $18-25$ & $20.00 \%$ & 5 \\
\hline $26-35$ & $10.00 \%$ & 8 \\
\hline $36-45$ & $16.00 \%$ & 14 \\
\hline $46-55$ & $28.00 \%$ & 8 \\
\hline $56-65$ & $16.00 \%$ & 5 \\
\hline $65+$ & $10.00 \%$ & 50
\end{tabular}

Q5 What time of day do you typically visit Tom Hanafan River's Edge Park? (select all that apply)

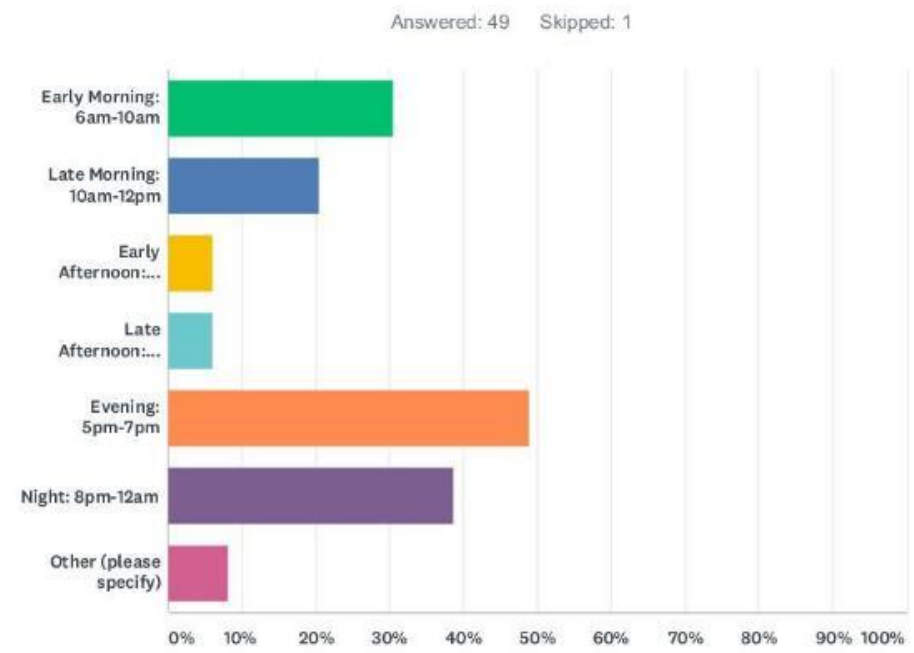

\begin{tabular}{lll}
\hline ANSWER CHOICES & RESPONSES & 15 \\
\hline Earty Morning: $6 \mathrm{am}-10 \mathrm{am}$ & $30.61 \%$ & 10 \\
\hline Late Moming: $10 \mathrm{am}-12 \mathrm{pm}$ & $20.41 \%$ & 3 \\
\hline Early Afternoon: $12 \mathrm{pm}-2 \mathrm{pm}$ & $6.12 \%$ & 3 \\
\hline Late Afternoon: $3 \mathrm{pm}-5 \mathrm{pm}$ & $6.12 \%$ & 24 \\
\hline Evening: $5 \mathrm{pm}-7 \mathrm{pm}$ & $48.98 \%$ & 19 \\
\hline Night: $8 \mathrm{pm}-12 \mathrm{am}$ & $38.78 \%$ & 4 \\
\hline Other (please specify) & $8.16 \%$ & \\
\hline Total Respondents: 49 & & \\
\end{tabular}


Q6 On average, how often do you visit Tom Hanafan River's Edge Park?

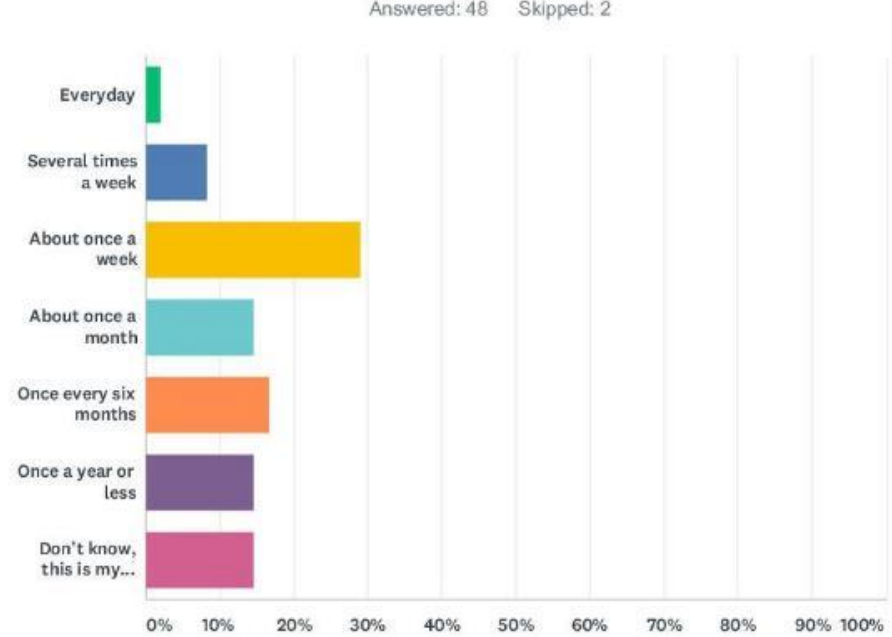

\begin{tabular}{|c|c|c|}
\hline ANSWER CHOICES & RESPONSES & \\
\hline Everyday & $2.08 \%$ & 1 \\
\hline Several times a week & $8.33 \%$ & 4 \\
\hline About once a week & $29.17 \%$ & 14 \\
\hline About once a month & $14.58 \%$ & 7 \\
\hline Once every six months & $16.67 \%$ & 8 \\
\hline Once a year or less & $14.58 \%$ & 7 \\
\hline Don't know, this is my first visit & $14.58 \%$ & 7 \\
\hline TOTAL & & 48 \\
\hline
\end{tabular}

Q7 How do you usually arrive to the park?

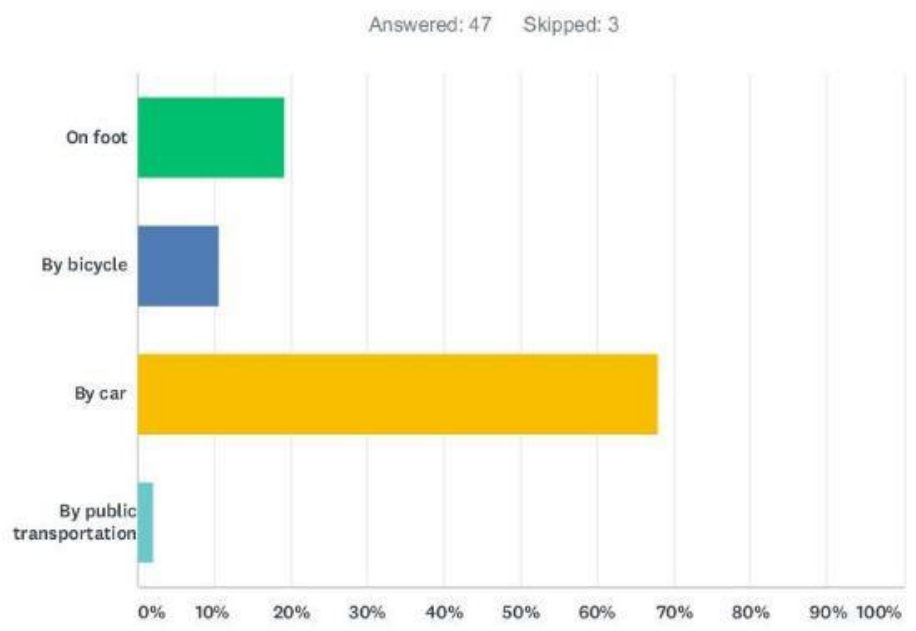

\begin{tabular}{|c|c|c|}
\hline ANSWER CHOICES & RESPONSES & \\
\hline On foot & $19.15 \%$ & 9 \\
\hline By bicycle & $10.64 \%$ & 5 \\
\hline By car & $68.09 \%$ & 32 \\
\hline By public transportation & $2.13 \%$ & 1 \\
\hline TOTAL & & 47 \\
\hline
\end{tabular}




\section{Q8 When you visit Tom Hanafan River's Edge Park, how long do you usually stay?}

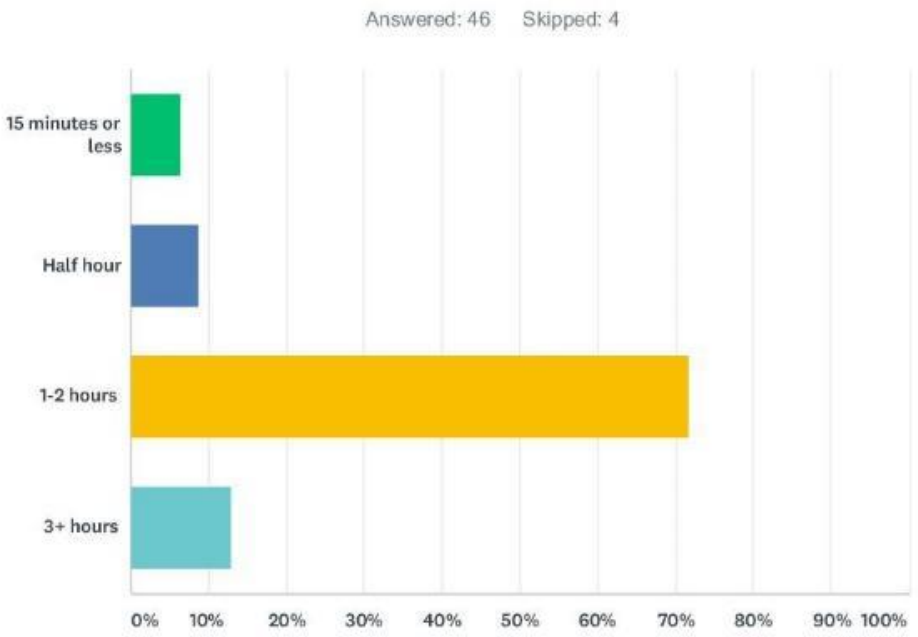

\begin{tabular}{|c|c|c|}
\hline ANSWER CHOICES & RESPONSES & \\
\hline 15 minutes or less & $6.52 \%$ & 3 \\
\hline Half hour & $8.70 \%$ & 4 \\
\hline $1-2$ hours & $71.74 \%$ & 33 \\
\hline $3+$ hours & $13.04 \%$ & 6 \\
\hline TOTAL & & 46 \\
\hline
\end{tabular}

\section{Q9 What do you think of when you think of Tom Hanafan River's Edge Park}

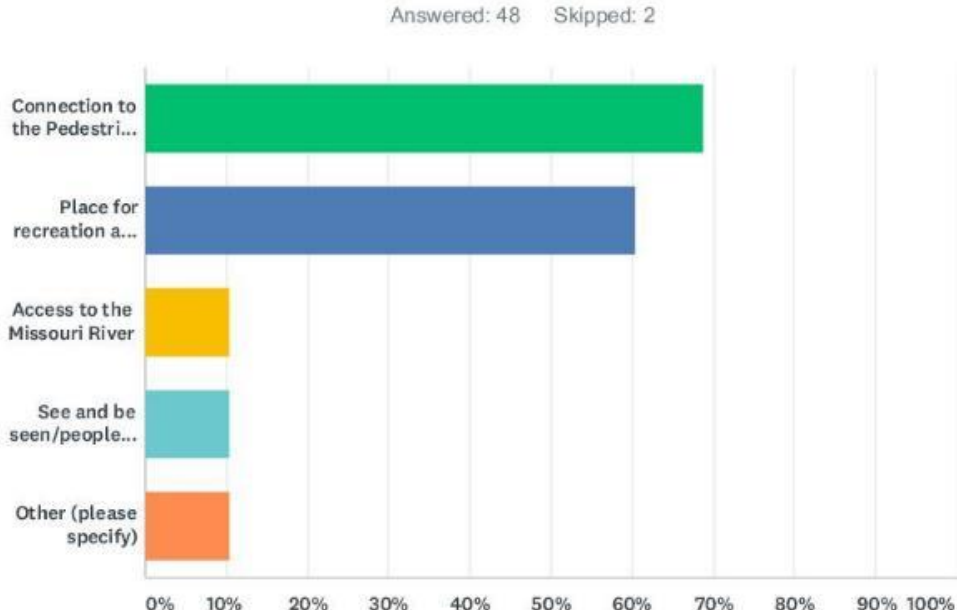

\begin{tabular}{|c|c|c|}
\hline ANSWER CHOICES & \multicolumn{2}{|c|}{ RESPONSES } \\
\hline Connection to the Pedestrian Bridge & $68.75 \%$ & 33 \\
\hline Place for recreation and events & $60.42 \%$ & 29 \\
\hline Access to the Missouri River & $10.42 \%$ & 5 \\
\hline See and be seen/people watching & $10.42 \%$ & 5 \\
\hline Other (please specify) & $10.42 \%$ & 5 \\
\hline Total Respondents: 48 & & \\
\hline
\end{tabular}


Q10 How would you rate the appearance of Tom Hanafan River's Edge

Park today?

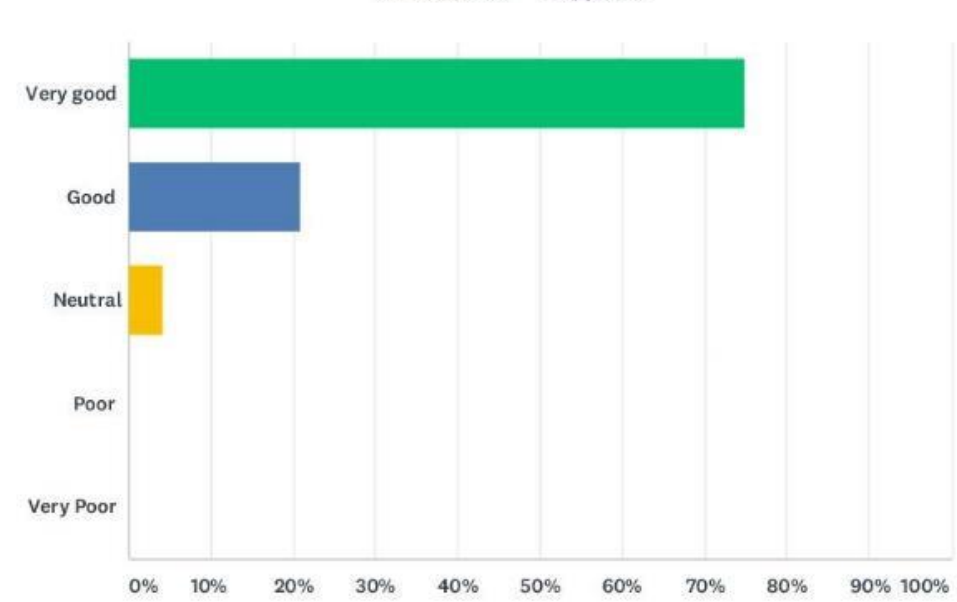

ANSWER CHOICES

\begin{tabular}{|c|c|c|}
\hline ANSWER CHOICES & RESPONSES & \\
\hline Very good & $75.00 \%$ & 36 \\
\hline Good & $20.83 \%$ & 10 \\
\hline Neutral & $4.17 \%$ & 2 \\
\hline Poor & $0.00 \%$ & 0 \\
\hline Very Poor & $0.00 \%$ & 0 \\
\hline TOTAL & & 48 \\
\hline
\end{tabular}


Q13 My motivation for visiting Tom Hanafan River's Edge Park is to... (select all that apply)

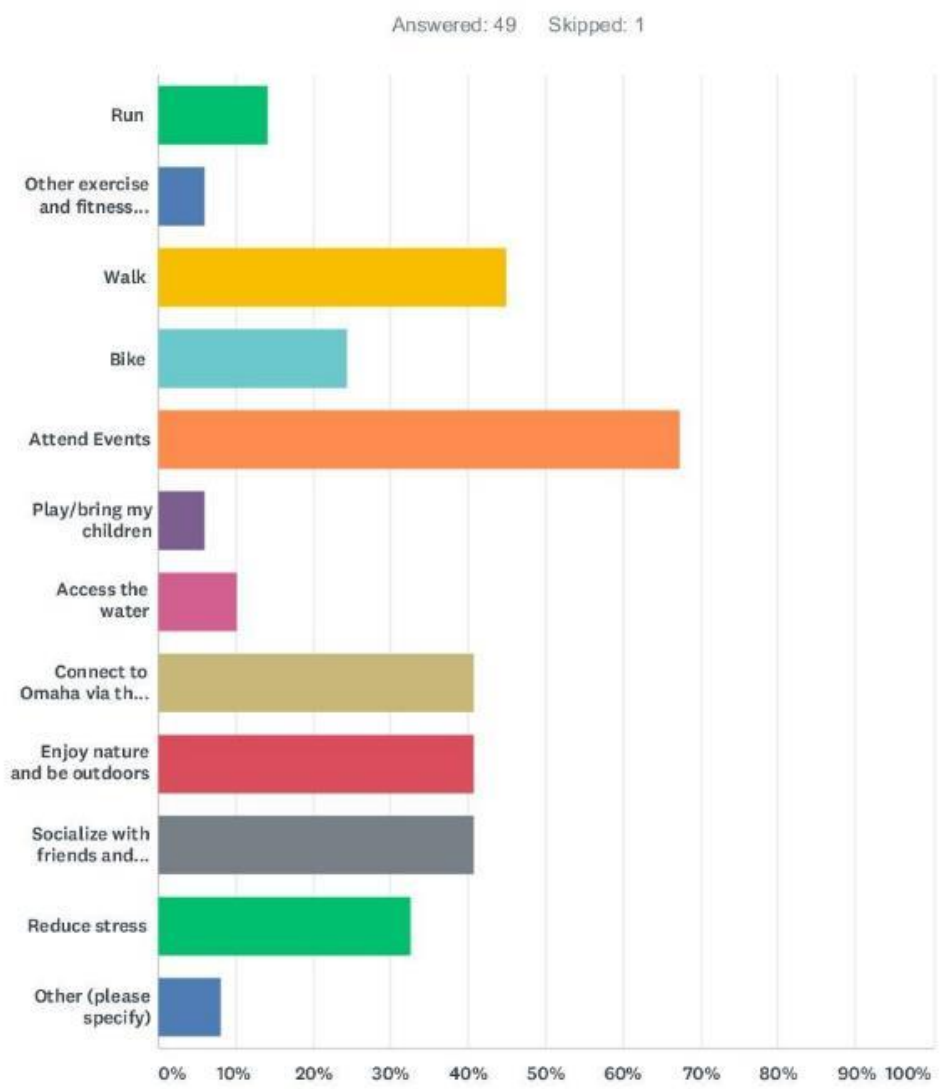

\begin{tabular}{|c|c|c|}
\hline ANSWER CHOICES & \multicolumn{2}{|c|}{ RESPONSES } \\
\hline Run & $14.29 \%$ & 7 \\
\hline Other exercise and fitness activities & $6.12 \%$ & 3 \\
\hline Walk & $44.90 \%$ & 22 \\
\hline Bike & $24.49 \%$ & 12 \\
\hline Attend Events & $67.35 \%$ & 33 \\
\hline Play/bring my children & $6.12 \%$ & 3 \\
\hline Access the water & $10.20 \%$ & 5 \\
\hline Connect to Omaha via the pedestrian bridge & $40.82 \%$ & 20 \\
\hline Enjoy nature and be outdoors & $40.82 \%$ & 20 \\
\hline Socialize with friends and family & $40.82 \%$ & 20 \\
\hline Reduce stress & $32.65 \%$ & 16 \\
\hline Other (please specify) & $8.16 \%$ & 4 \\
\hline Total Respondents: 49 & & \\
\hline
\end{tabular}




\section{Q14 What activities do you participate in while visiting Tom Hanafan River's Edge Park? (select all that apply)}

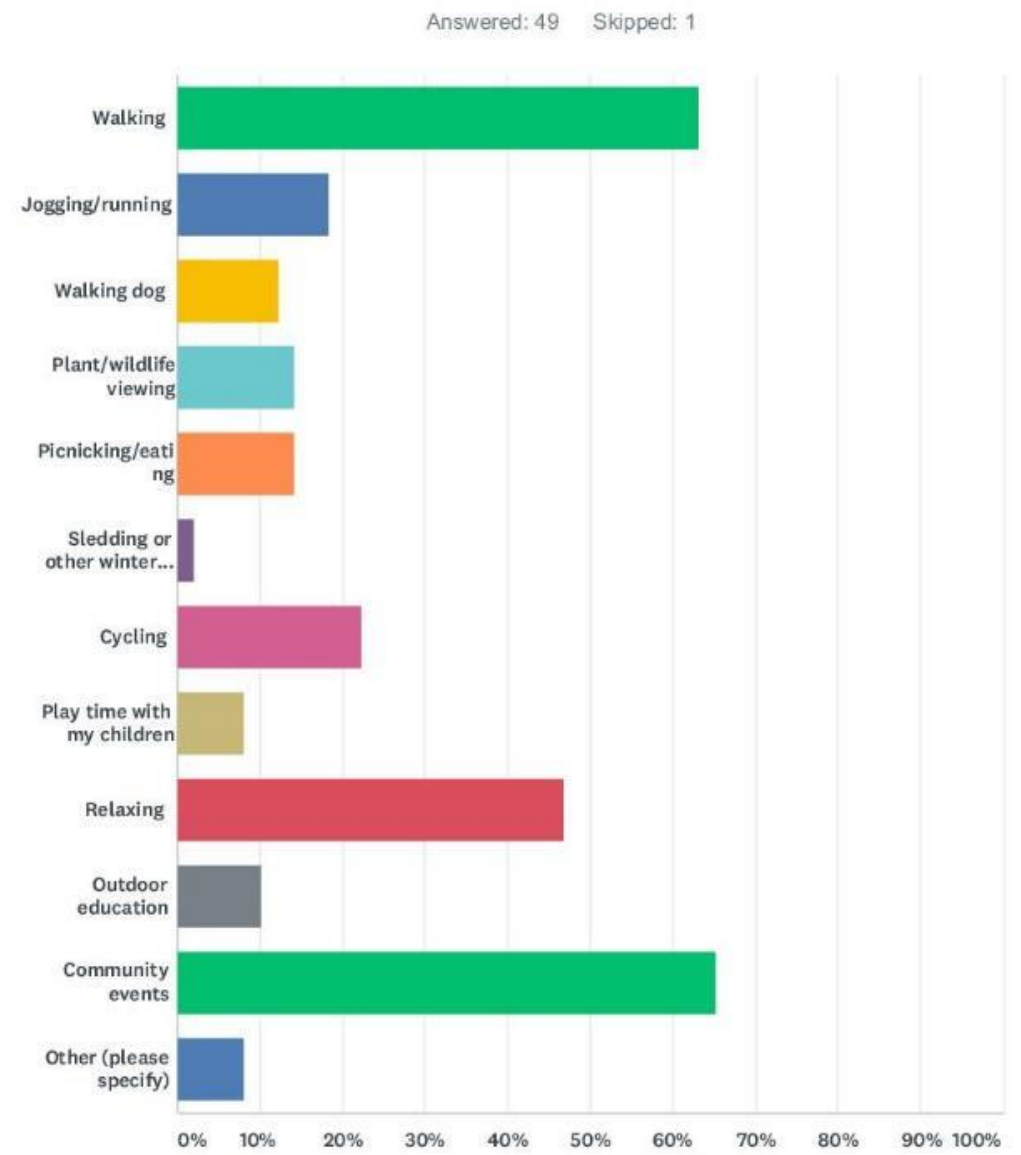

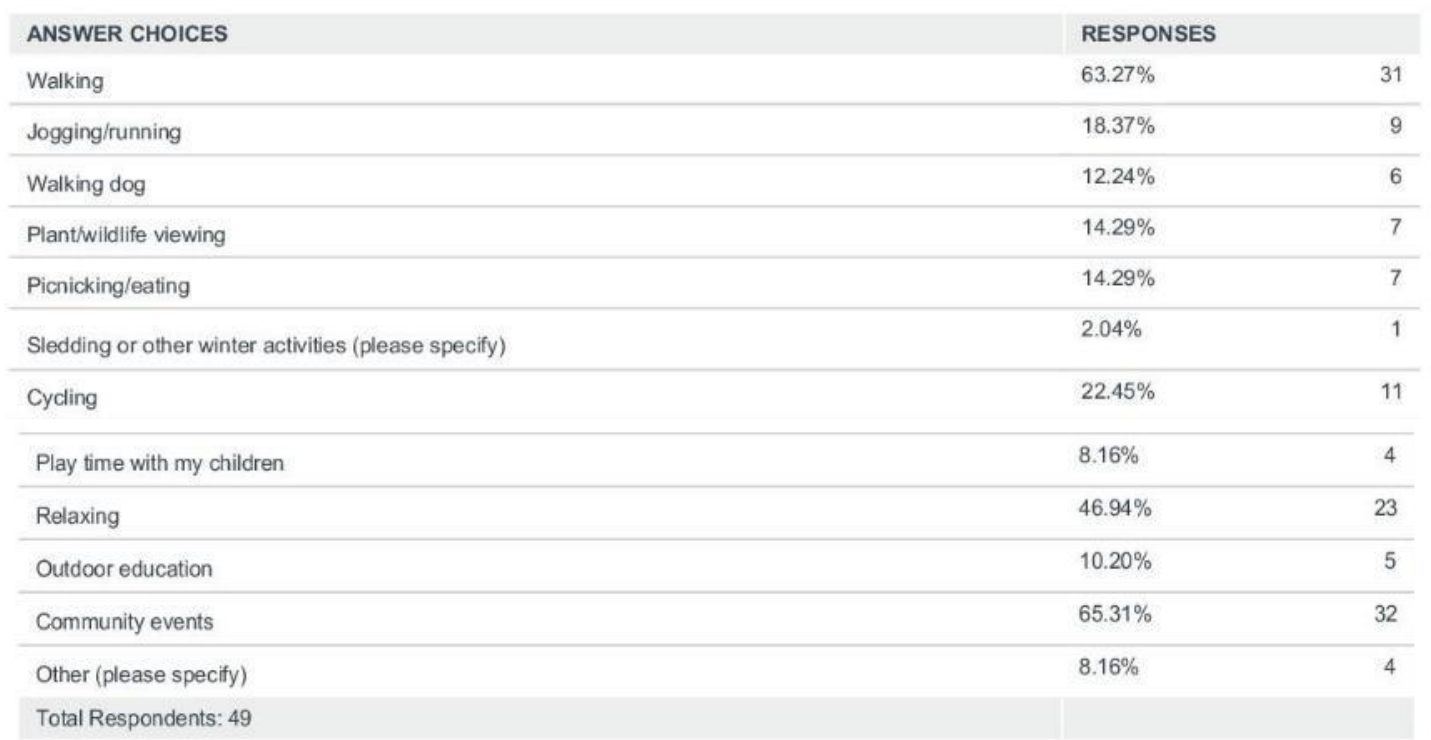


Q15 Tom Hanafan River's Edge Park

(select all that

apply):

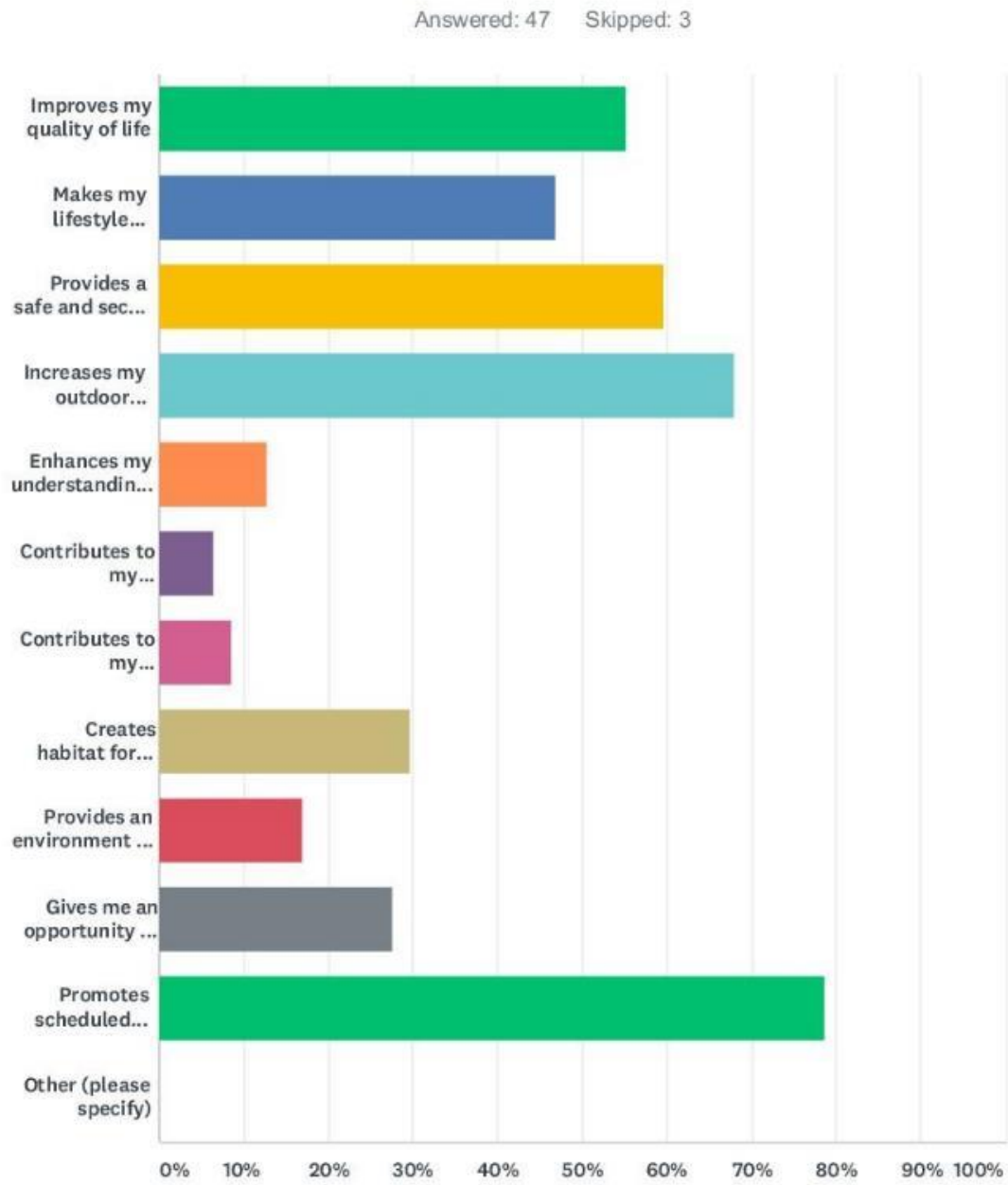

\begin{tabular}{|c|c|c|}
\hline ANSWER CHOICES & \multicolumn{2}{|c|}{ RESPONSES } \\
\hline Improves my quality of life & $55.32 \%$ & 26 \\
\hline Makes my lifestyle healthier & $46.81 \%$ & 22 \\
\hline Provides a safe and secure environment & $59.57 \%$ & 28 \\
\hline Increases my outdoor activity & $68.09 \%$ & 32 \\
\hline Enhances my understanding of the site's flooding capacity & $12.77 \%$ & 6 \\
\hline Contributes to my understanding of alternative stormwater management practice & $6.38 \%$ & 3 \\
\hline Contributes to my understanding of floodplain forest ecology & $8.51 \%$ & 4 \\
\hline Creates habitat for wildlife & $29.79 \%$ & 14 \\
\hline Provides an environment to see artwork & $17.02 \%$ & 8 \\
\hline Gives me an opportunity to learn something new & $27.66 \%$ & 13 \\
\hline Promotes scheduled outdoor events & $78.72 \%$ & 37 \\
\hline Other (please specify) & $0.00 \%$ & 0 \\
\hline Total Respondents: 47 & & \\
\hline
\end{tabular}


Q16 Have you ever attended an event held in Tom Hanafan River's Edge Park?

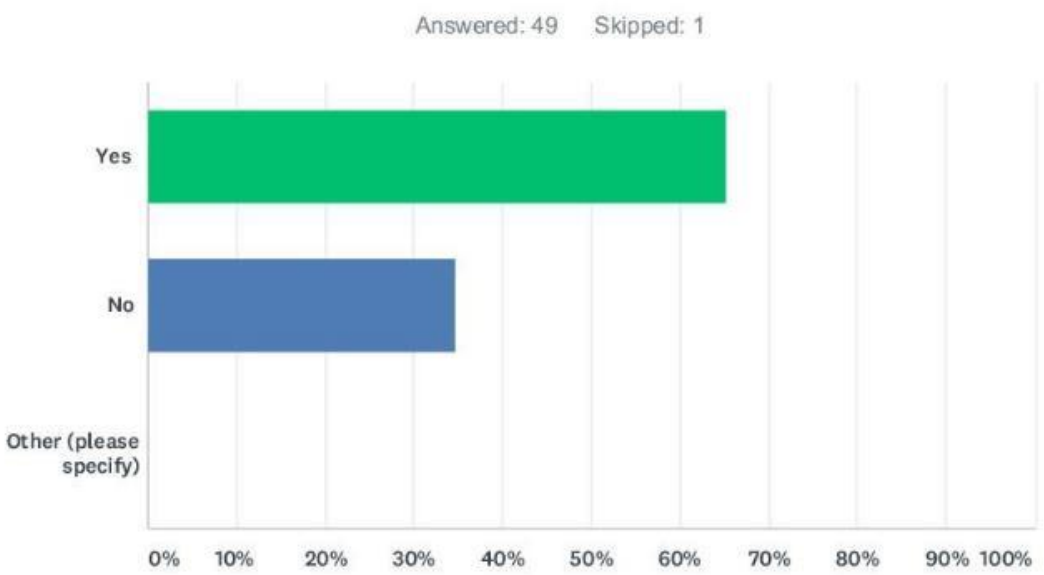

\begin{tabular}{l|l|l} 
ANSWER CHOICES & RESPONSES \\
\hline Yes & $65.31 \%$ & 32 \\
\hline No & $34.69 \%$ & 17 \\
\hline Other (please specify) & $0.00 \%$ & 0 \\
TOTAL & & 49
\end{tabular}

Q17 If you answered no, would you be interested in attending an event if it is held in Tom Hanafan River's Edge Park?

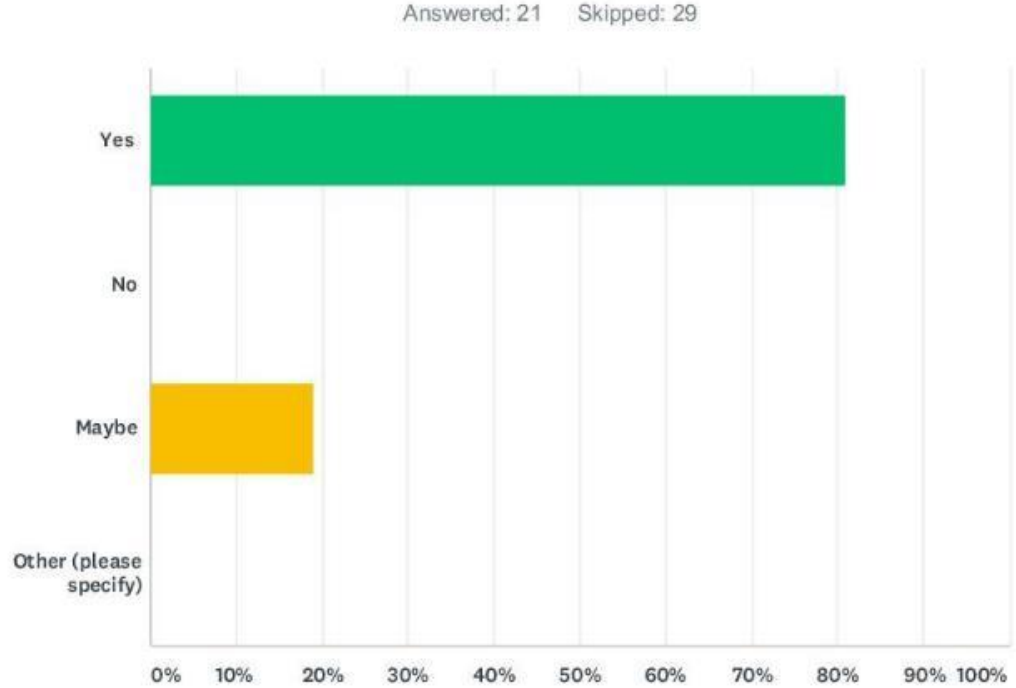

\begin{tabular}{|c|c|c|}
\hline ANSWER CHOICES & RESPONSES & \\
\hline Yes & $80.95 \%$ & 17 \\
\hline No & $0.00 \%$ & 0 \\
\hline Maybe & $19.05 \%$ & 4 \\
\hline Other (please specify) & $0.00 \%$ & 0 \\
\hline
\end{tabular}


Q19 Within the Tom Hanafan River's Edge Park, I feel the quantity of parking is...

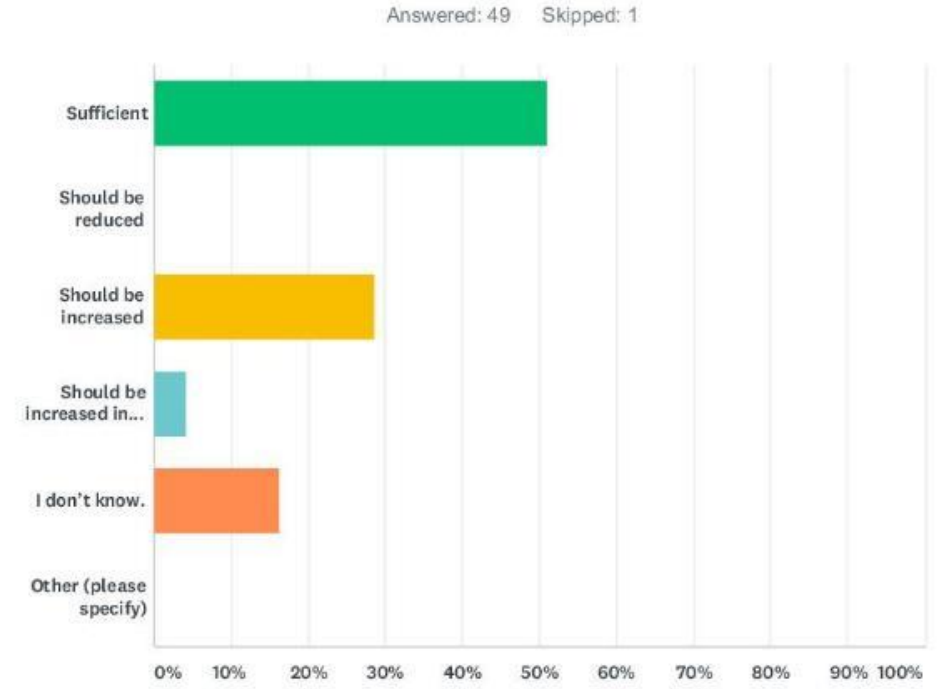

\begin{tabular}{|c|c|c|}
\hline ANSWER CHOICES & \multicolumn{2}{|c|}{ RESPONSES } \\
\hline Sufficient & $51.02 \%$ & 25 \\
\hline Should be reduced & $0.00 \%$ & 0 \\
\hline Should be increased & $28.57 \%$ & 14 \\
\hline Should be increased in the form of parking garages & $4.08 \%$ & 2 \\
\hline I don't know. & $16.33 \%$ & 8 \\
\hline Other (please specify) & $0.00 \%$ & 0 \\
\hline TOTAL & & 49 \\
\hline
\end{tabular}

Q20 How would you rate your satisfaction with the amount of bike parking in Tom Hanafan River's Edge Park?

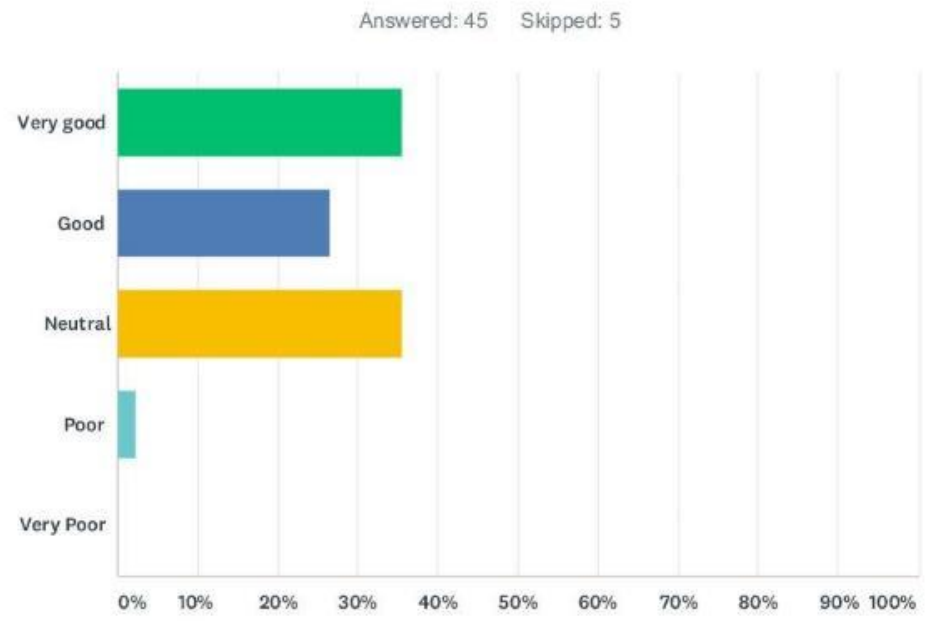

\begin{tabular}{llr} 
ANSWER CHOICES & RESPONSES & 16 \\
Very good & $35.56 \%$ & 12 \\
\hline Good & $26.67 \%$ & 16 \\
\hline Neutral & $35.56 \%$ & 1 \\
\hline Poor & $2.22 \%$ & 0 \\
\hline Very Poor & $0.00 \%$ & 45
\end{tabular}


Q22 Are you familiar with what Tom Hanafan River's Edge Park looked like before it became a public park?

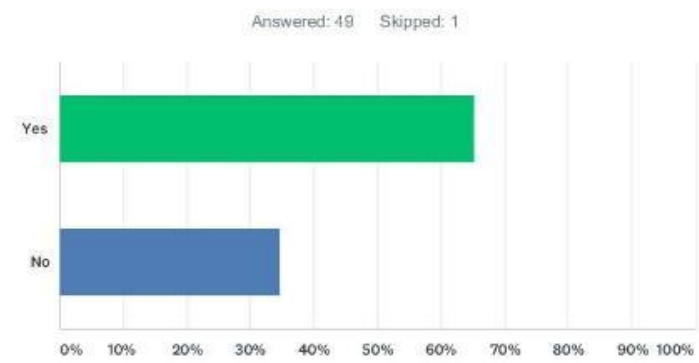

\begin{tabular}{llr} 
ANSWER CHOICES & RESPONSES & 32 \\
YES & $65.31 \%$ & 17 \\
\hline NO & $34.69 \%$ & 49
\end{tabular}

Q23 Do you find access to the Missouri river from Tom Hanafan River's Edge Park easier or more difficult after the reconstruction? How much easier or more difficult?

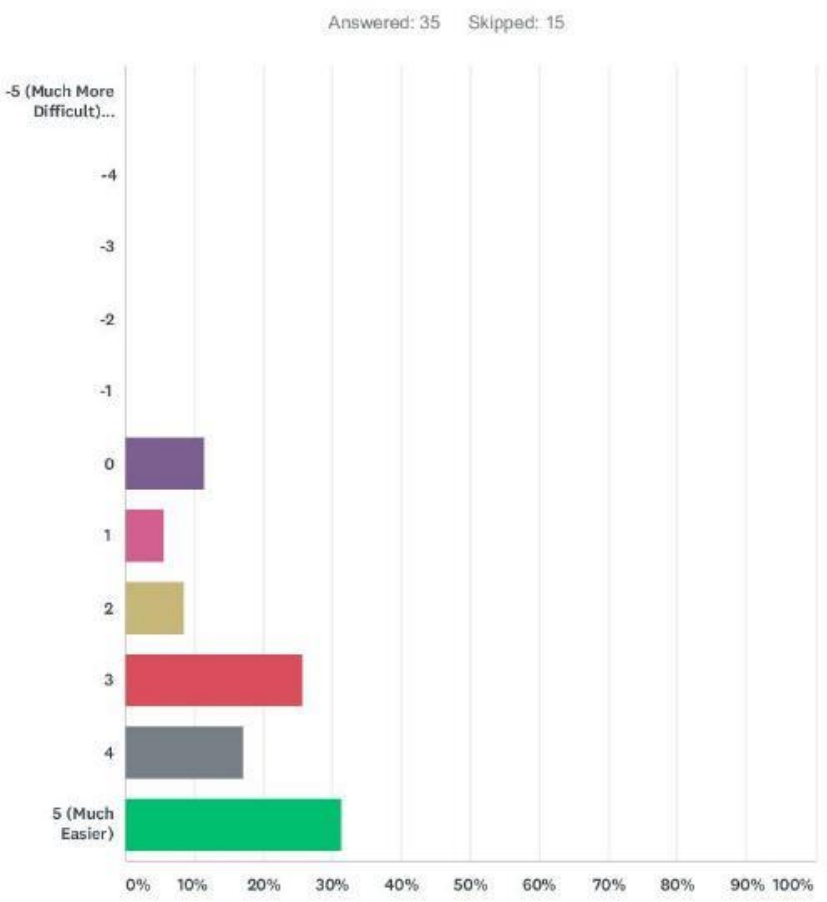

\begin{tabular}{llr} 
ANSWER CHOICES & RESPONSES & 0 \\
\hline-5 (Much More Difficult) & $0.00 \%$ & 0 \\
\hline-4 & $0.00 \%$ & 0 \\
\hline-3 & $0.00 \%$ & 0 \\
\hline-2 & $0.00 \%$ & 0 \\
\hline-1 & $0.00 \%$ & 4 \\
\hline 0 & $11.43 \%$ & 2 \\
\hline 1 & $5.71 \%$ & 3 \\
\hline 2 & $8.57 \%$ & 9 \\
\hline 3 & $25.71 \%$ & 6 \\
\hline 4 & $17.14 \%$ & 11 \\
\hline 5 (Much Easier) & $31.43 \%$ & 35
\end{tabular}


Q24 Do you feel safer and more comfortable using Tom Hanafan River's Edge Park at all times of the day after the reconstruction? How much safer and more comfortable?

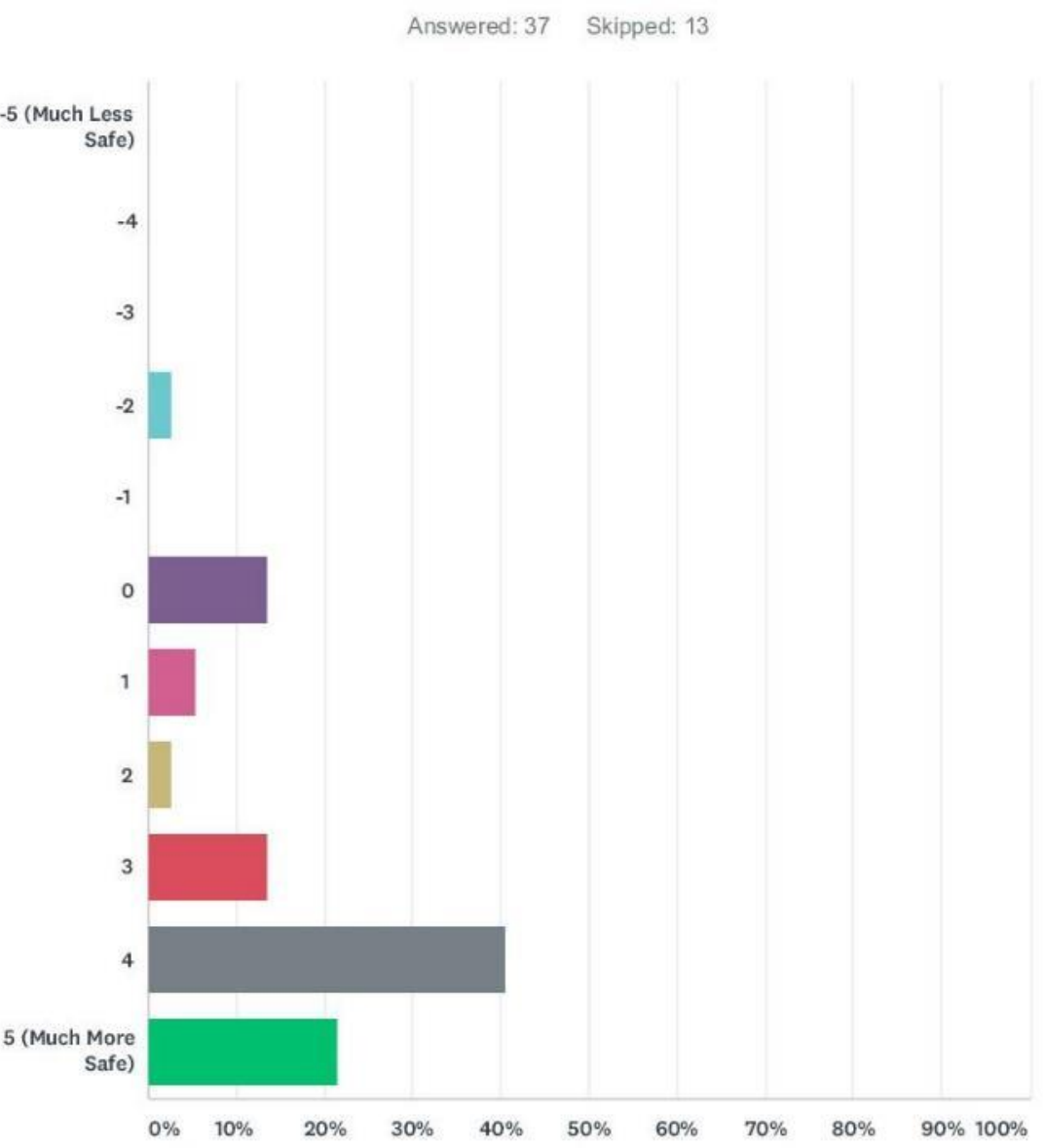

\begin{tabular}{llr} 
ANSWER CHOICES & RESPONSES & 0 \\
\hline-5 (Much Less Safe) & $0.00 \%$ & 0 \\
\hline-4 & $0.00 \%$ & 0 \\
\hline-3 & $0.00 \%$ & 1 \\
\hline-2 & $2.70 \%$ & 0 \\
\hline-1 & $0.00 \%$ & 5 \\
\hline 0 & $13.51 \%$ & 2 \\
\hline 1 & $5.41 \%$ & 1 \\
\hline 2 & $2.70 \%$ & 5 \\
\hline 3 & $13.51 \%$ & 15 \\
\hline 4 & $40.54 \%$ & 8 \\
\hline 5 (Much More Safe) & $21.62 \%$ & 37
\end{tabular}


Q25 Are you aware that the park contributes to the flood resiliency of Council Bluffs?

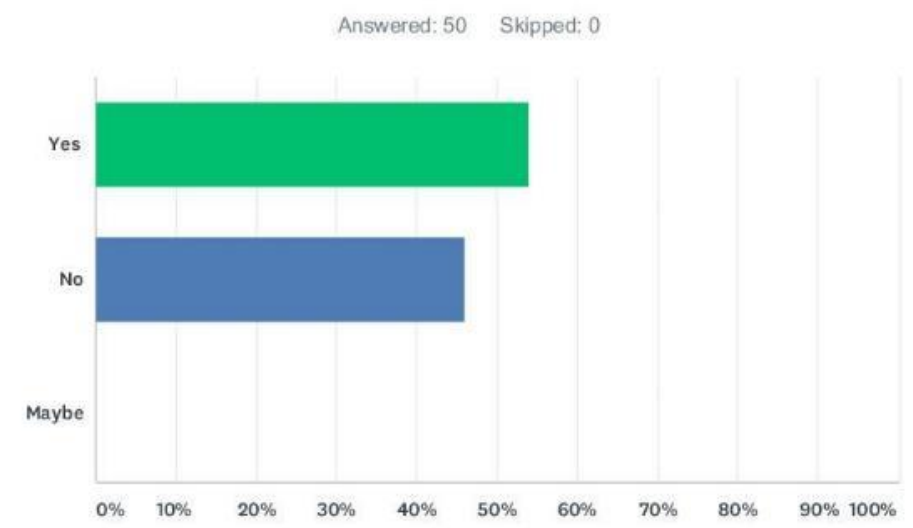

\begin{tabular}{|c|c|c|}
\hline ANSWER CHOICES & RESPONSES & \\
\hline Yes & $54.00 \%$ & 27 \\
\hline No & $46.00 \%$ & 23 \\
\hline Maybe & $0.00 \%$ & 0 \\
\hline TOTAL & & 50 \\
\hline
\end{tabular}

Q26 If not, would you like to learn more?

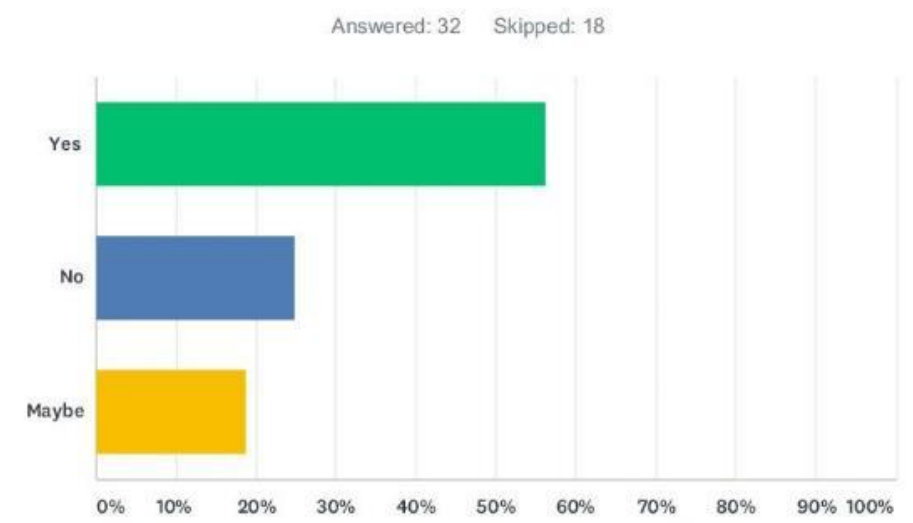

ANSWER CHOICES

RESPONSES

Yes

$56.25 \%$

$25.00 \%$

No

$18.75 \%$ 
Q27 What new ways could Tom Hanafan River's Edge Park educate those about the environmental benefits that the site offers to the community?

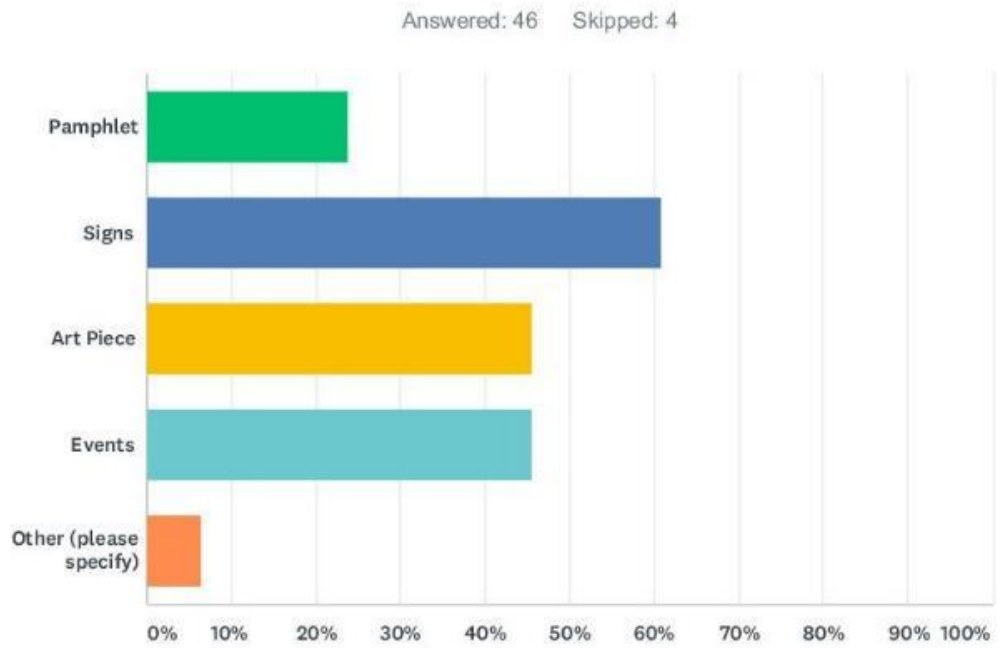

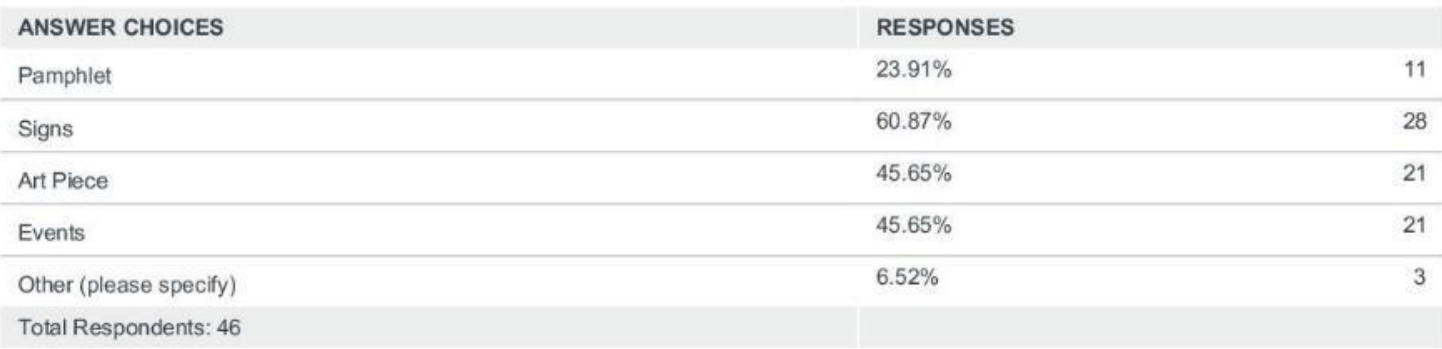

Q28 Do the ecological restoration and flood control benefits influence your desire to come visit the park?

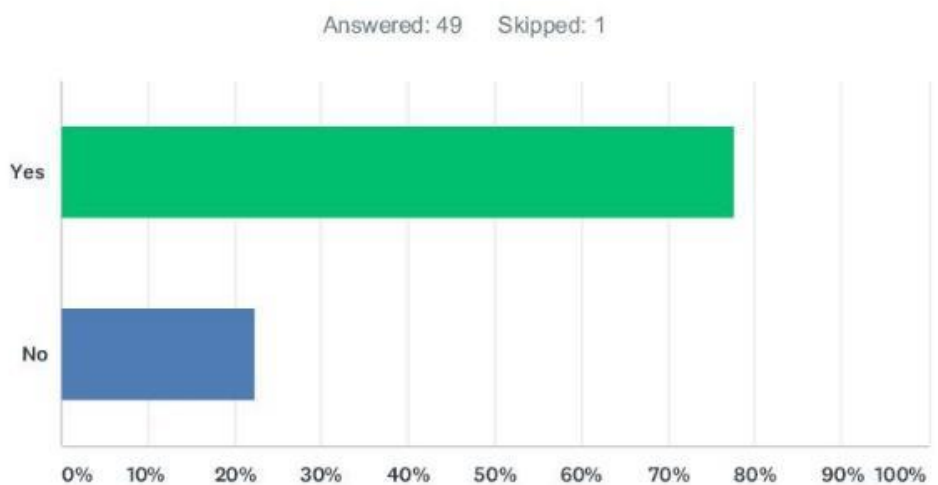

ANSWER CHOICES

Yes

No

TOTAL
RESPONSES

$77.55 \%$

$22.45 \%$ 


\section{Appendix B: EPA National Stormwater Calculator Report}

\section{National Stormwater Calculator Report \\ Site Description}

Tom Hanafan River's Edge Park

\begin{tabular}{|l|l|l|}
\hline Parameter & Current Scenario & Baseline Scenario \\
\hline Site Area (acres) & 21.64 & \\
\hline Hydrologic Soil Group & A & \\
\hline Hydraulic Conductivity (in/hr) & 1.1 & \\
\hline Surface Slope (\%) & 5 & \\
\hline Precip. Data Source & OMAHA EPPLEY AIRFIE... & \\
\hline Evap. Data Source & OMAHA EPPLEY AIRFIE... & \\
\hline Climate Change Scenario & Median/Near Term & \\
\hline$\%$ Forest & 39 & \\
\hline$\%$ Meadow & 7 & \\
\hline$\%$ Lawn & 29 & \\
\hline$\%$ Desert & 1 & \\
\hline$\%$ Impervious & 24 & \\
\hline Years Analyzed & 20 & \\
\hline Ignore Consecutive Wet Days & False & \\
\hline Wet Day Threshold (inches) & 0.10 & \\
\hline LID Control & Current Scenario & \\
\hline Disconnection & 0 & \\
\hline Rain Harvesting & 0 & \\
\hline Rain Gardens & 0 & \\
\hline Green Roofs & 0 & \\
\hline Street Planters & 0 & \\
\hline Infiltration Basins & 0 & \\
\hline Porous Pavement & $9 / 100$ & \\
\hline
\end{tabular}

$\%$ of impervious area treated $/ \%$ of treated area used for LID 


\section{National Stormwater Calculator Report Summary Results}

Tom Hanafan River's Edge Park

\begin{tabular}{|l|r|r|}
\hline Statistic & Current Scenario & Baseline Scenario \\
\hline Average Annual Rainfall (inches) & 17.77 & \\
\hline Average Annual Runoff (inches) & 3.47 & \\
\hline Days per Year With Rainfall & 32.98 & \\
\hline Days per Year with Runoff & 10.79 & \\
\hline Percent of Wet Days Retained & 67.27 & \\
\hline Smallest Rainfall w/ Runoff (inches) & 0.42 & \\
\hline Largest Rainfall w/o Runoff (inches) & 0.58 & \\
\hline Max. Rainfall Retained (inches) & 3.33 & \\
\hline
\end{tabular}

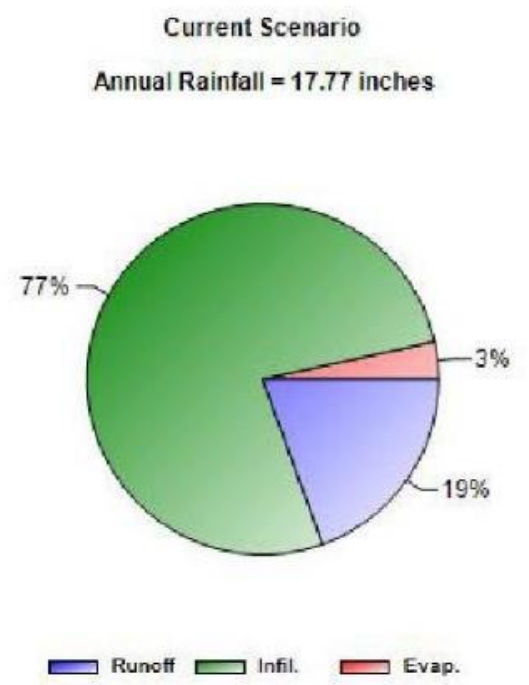




\section{National Stormwater Calculator Report}
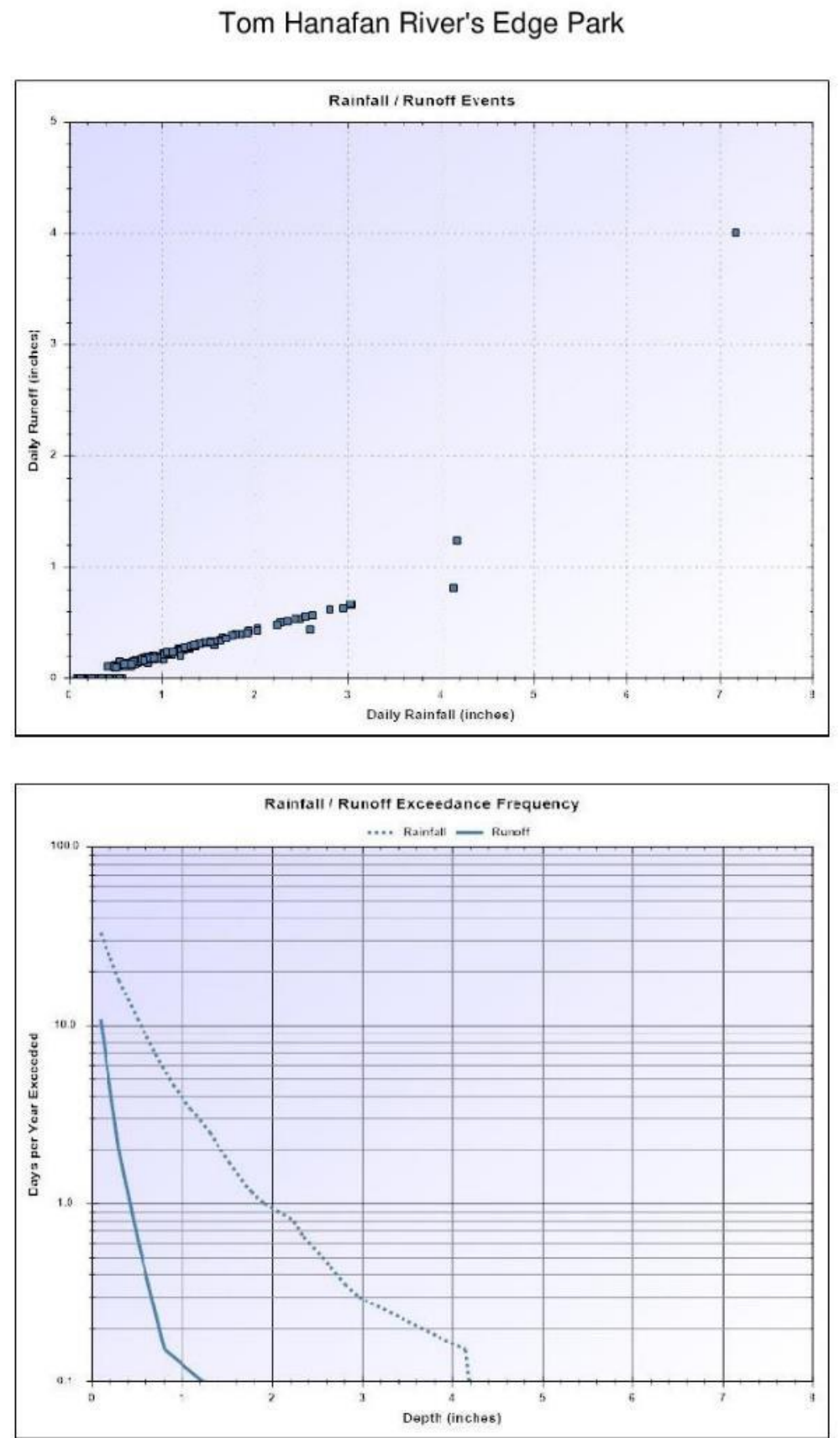


\section{National Stormwater Calculator Report}

\section{Tom Hanafan River's Edge Park}
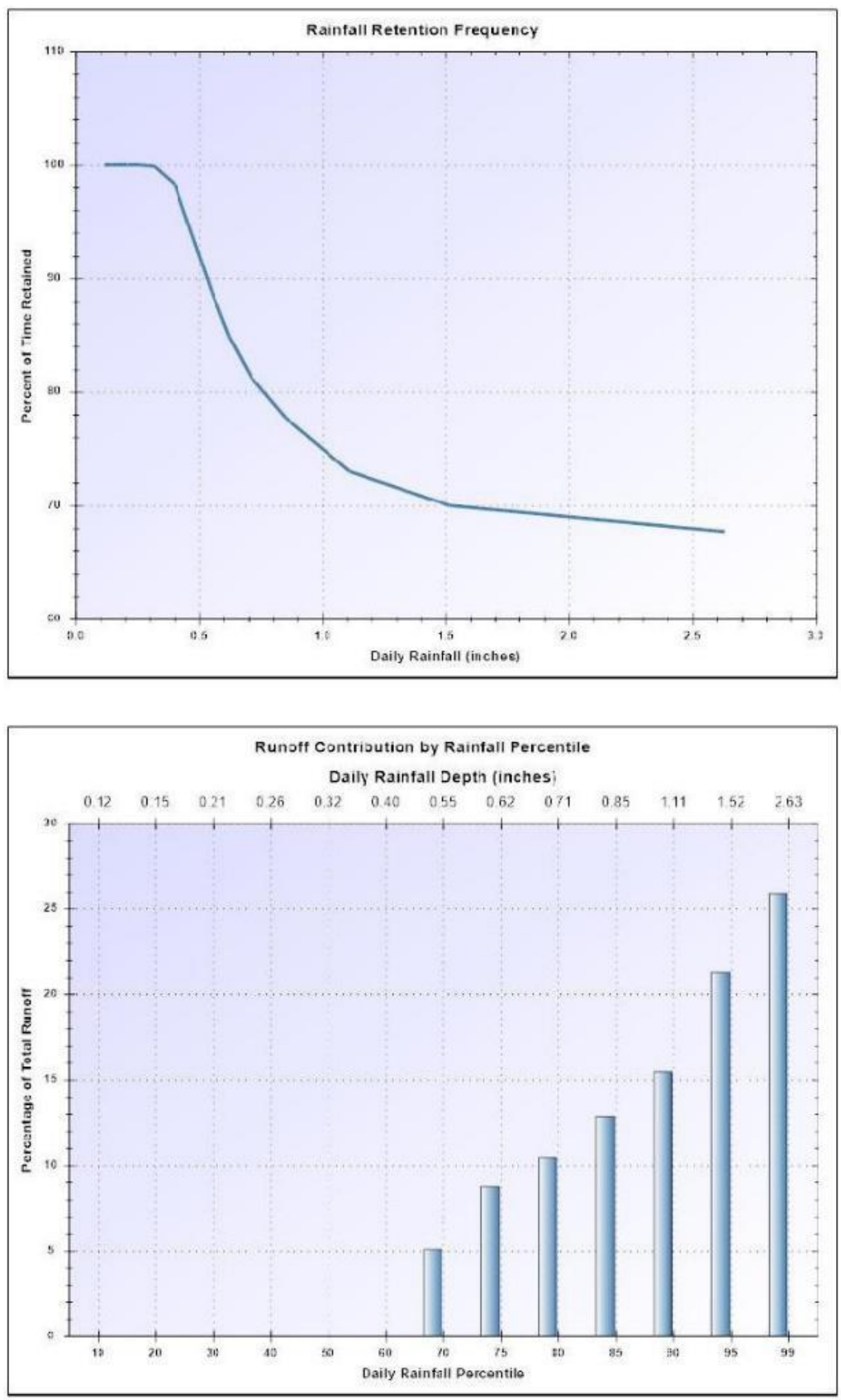


\section{National Stormwater Calculator Report}

Tom Hanafan River's Edge Park
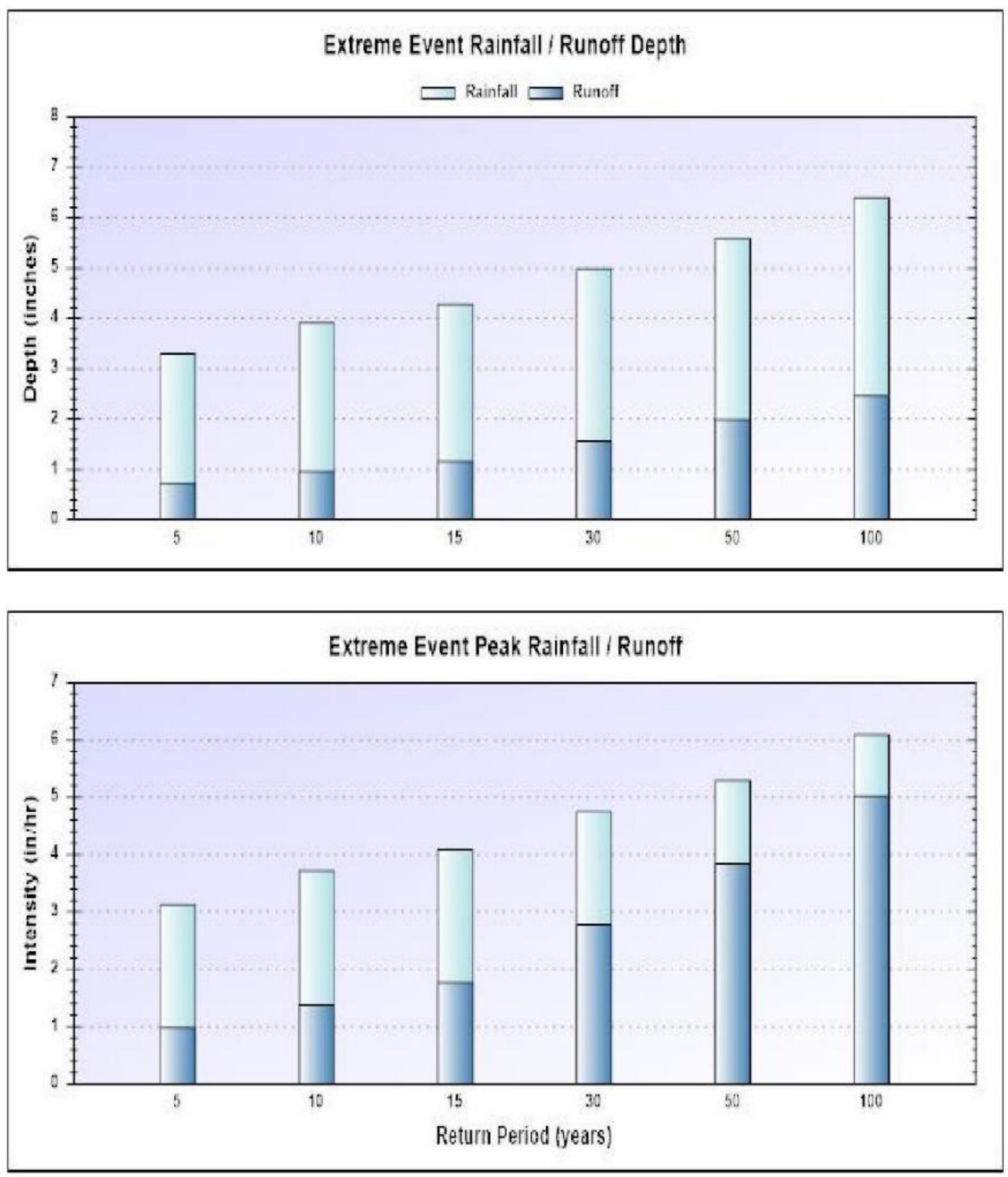


\section{National Stormwater Calculator Report Estimate of Probable Costs}

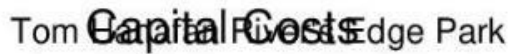

\begin{tabular}{|l|l|l|l|}
\hline LID Control & Current Scenario & Baseline Scenario & Cost Difference \\
\hline Disconnection & $\$-\$$ & & \\
\hline Rainwater Harvesting & $\$-\$$ & & \\
\hline Rain Gardens & $\$-\$$ & & \\
\hline Green Roofs & $\$-\$$ & & \\
\hline Street Planters & $\$-\$$ & & \\
\hline Infiltration Basins & $\$-\$$ & & \\
\hline Permeable Pavement & $\$ 406,300-\$ 542,200$ & & \\
\hline Total & $\$ 406,300-\$ 542,200$ & & \\
\hline
\end{tabular}

\section{Maintenance Costs}

\begin{tabular}{|l|l|l|l|}
\hline LID Control & Current Scenario & Baseline Scenario & Cost Difference \\
\hline Disconnection & $\$-\$$ & & \\
\hline Rainwater Harvesting & $\$-\$$ & & \\
\hline Rain Gardens & $\$-\$$ & & \\
\hline Green Roofs & $\$-\$$ & & \\
\hline Street Planters & $\$-\$$ & & \\
\hline Infiltration Basins & $\$-\$$ & & \\
\hline Permeable Pavement & $\$ 4,800-\$ 26,300$ & & \\
\hline Total & $\$ 4,800-\$ 26,300$ & & \\
\hline
\end{tabular}




\section{Appendix C: City of Council Bluffs Fiscal Year 2017 Budget to Actual Revenue Comparison Chart}

City of Council Bluffs

Fiscal Year 2017 Budget to Actual Revenue Comparison 11 month period ending May 31, 2017

\begin{tabular}{|c|c|c|c|c|c|}
\hline \multirow{2}{*}{$\begin{array}{l}\text { State Budge } \\
\text { Reference }\end{array}$} & \multirow[b]{2}{*}{ Revenue Description } & \multirow{2}{*}{$\begin{array}{c}\text { Budget } \\
\text { FY } 2017\end{array}$} & \multirow{2}{*}{$\begin{array}{c}\text { YTD Actual } \\
05 / 31 / 2017\end{array}$} & \multirow{2}{*}{$\begin{array}{c}\% \text { Collected } \\
05 / 31 / 2017\end{array}$} & \multirow{2}{*}{$\begin{array}{l}\text { YTD Actual } \\
05 / 31 / 2016\end{array}$} \\
\hline & & & & & \\
\hline & Police Services Fees & 29,500 & 70,272 & $238.21 \%$ & 38,155 \\
\hline & Fire Suppression Fees & - & 136 & $100.00 \%$ & 136 \\
\hline & Fire Technical Fees & - & 9,200 & $100.00 \%$ & - \\
\hline & Animal Control Fees & 10,000 & 7,714 & $77.14 \%$ & 7,655 \\
\hline & Public Health Inspection Fees & 2,500 & 6,338 & $253.52 \%$ & 6,111 \\
\hline & Library Fees & 43,000 & 44,590 & $103.70 \%$ & 46,014 \\
\hline & Parks Administrative Fees & 3,000 & 2,400 & $80.00 \%$ & 1,157 \\
\hline & Parks Recreation Fees & - & 1,000 & $100.00 \%$ & - \\
\hline & Parks Dodge Golf Fees & 42,000 & 895 & $2.13 \%$ & 19,120 \\
\hline & Parks Pool Fees & 65,000 & 30,288 & $46.60 \%$ & 32,203 \\
\hline & Parks Cemetery Fees & 2,500 & 2,014 & $80.56 \%$ & 1,675 \\
\hline & PW Equipment Maintenance & - & 4,520 & $100.00 \%$ & 3,887 \\
\hline & General Government Fees & $1,173,500$ & $1,083,357$ & $92.32 \%$ & $1,063,228$ \\
\hline & General Revenues & - & 150,000 & $100.00 \%$ & - \\
\hline & Other Indemnities & 1,000 & 1,005 & $100.48 \%$ & 962 \\
\hline & Other Indemnities & 150,000 & - & $0.00 \%$ & 75,000 \\
\hline & Reimbursement Restitution & - & 224 & $100.00 \%$ & 457 \\
\hline & Other Indemnities & - & - & $0.00 \%$ & 13 \\
\hline & CD Non Capital Projects & - & - & $100.00 \%$ & 753,941 \\
\hline & Other Indemnities Received & - & 41,666 & $100.00 \%$ & 43,533 \\
\hline & Federal Grant & - & 584 & $100.00 \%$ & 1,046 \\
\hline & Miscellaneous Grants & - & 155,100 & $100.00 \%$ & 120,400 \\
\hline & Loessfest 2016 & - & 129,217 & $100.00 \%$ & 236,000 \\
\hline & Misc. Government Donations & - & 180,575 & $100.00 \%$ & 128,101 \\
\hline & Reimbursements & - & 312,765 & $100.00 \%$ & $1,191,312$ \\
\hline & Forfeited Assets & - & 893 & $100.00 \%$ & 1,708 \\
\hline & Other & 225,000 & - & $0.00 \%$ & - \\
\hline Line 36 & \multirow[t]{3}{*}{ Miscellaneous } & $1,763,700$ & $2,277,135$ & $129.11 \%$ & $3,823,329$ \\
\hline Line 37 & & $15,024,727$ & $15,623,377$ & $103.98 \%$ & $7,353,893$ \\
\hline \multirow[t]{3}{*}{ Line 41} & & 140,755 & 93,083 & $66.13 \%$ & 82,451 \\
\hline & GENEREAL FUND REVENUE TOTAL & $61,788,471$ & $58,085,331$ & $94.01 \%$ & $51,044,990$ \\
\hline & SPECIAL REVENUE FUND & \multicolumn{4}{|c|}{ REVENUE } \\
\hline \multicolumn{6}{|c|}{ TAXES LEVIED ON PROPERTY: } \\
\hline & Taxes Levied on Property Emergency Fund & 638,179 & 618,527 & $96.92 \%$ & 591,394 \\
\hline & Taxes Levied on Property - Employee Benefit Fund & $13,895,535$ & $13,467,643$ & $96.92 \%$ & $12,344,955$ \\
\hline & Taxes Levied on Property-Lake Manawa SSMID & 125,000 & 128,295 & $102.64 \%$ & 130,907 \\
\hline Line 3 & Total Net Current Property Taxes & $14,658,714$ & $14,214,465$ & $96.97 \%$ & $13,067,256$ \\
\hline \multicolumn{6}{|c|}{ OTHER CITY TAXES: } \\
\hline \multirow{5}{*}{ Line 6} & Utility Tax Replacement - Emergency Fund & 49,699 & 49,633 & $99.87 \%$ & 57,428 \\
\hline & Utility Tax Replacement - Employee Benefit Fund & $1,082,138$ & $1,080,699$ & $99.87 \%$ & $1,198,773$ \\
\hline & Utility Tax Replacement Excise Tax & $1,131,837$ & $1,130,332$ & $99.87 \%$ & $1,256,201$ \\
\hline & Other Revenue & - & $2,373,746$ & $100.00 \%$ & $2,742,761$ \\
\hline & Local Option Sales Tax-Roads & $8,900,000$ & $6,974,690$ & $78.37 \%$ & $8,252,432$ \\
\hline
\end{tabular}

$43 \quad 3$ 